\title{
LA RISA NATAL. FUNDAMENTOS ANTROPOLÓGICOS Y RELIGIOSOS DE LA COMICIDAD CLERICAL EN NAVIDAD
}

\author{
POR \\ ALBERTO DEL CAMPO TEJEDOR \\ Universidad Pablo de Olavide (Sevilla)
}

\section{RESUMEN}

La comicidad de muchas de las fiestas populares y clericales del ciclo invernal ha sido interpretada mayoritariamente como supervivencia pagana y profana, contraria a la fe cristiana. Este artículo discute esta tesis reduccionista y aporta evidencias que permiten comprender las pugnas entre detractores y simpatizantes de las polémicas fiestas burlescas en torno a la Navidad. Para ello se indaga el tipo de alegría pascual que cierta teología ha justificado en atención a razones como la eutrapelia o el carácter ejemplar de la humillación y la humildad en los rituales de inversión de roles. La risa navideña se muestra como un ingrediente fundamental de una mito-lógica en la que la turbulencia, la jovialidad, incluso la obscenidad, constituyen formas liminales de colaborar en el eterno ciclo de nacimiento, muerte y resurrección.

\section{PALABRAS CLAVE}

Navidad; fiestas clericales; risa; eutrapelia; humillación; sátira; ritos de paso.

\section{CHRISTMAS LAUGH. ANTHROPOLOGICAL AND RELIGIOUS FOUNDATIONS OF CLERICAL COMICALNESS ON CHRISTMAS}

\section{ABSTRACT}

The comicalness of many of the popular and clerical festivals in the winter cycle has been mostly interpreted as a pagan and profane survival, objected to Christian faith. This paper discusses this simplistic thesis and adduces evidences that allows to understand the struggles between detractors and sympathizers of the polemic burlesque festivals on 
Christmas. We study the type of paschal joy that certain theology has justified in consideration of reasons such as the eutrapelia or the exemplary character of the humiliation and the humility in rituals based on investment of roles. Christmas laugh appears then as a fundamental ingredient of a mytho-logic in which turbulence, joviality, even obscenity, constitute liminal forms in collaborating with the eternal cycle of birth, death and resurrection.

\section{KEY WORDS}

Christmas; clerical festivals; laugh; eutrapelia; humiliation; satire; rites of passage.

$\begin{array}{ll}\text { Recibido/Received } & 23-04-2013 \\ \text { Aceptado/Accepted } & 03-03-2014\end{array}$

\section{INTRODUCCIÓN}

Dos son las características destacadas por la mayoría de estudios históricos y antropológicos sobre las fiestas populares del ciclo invernal, especialmente con respecto a las celebraciones situadas entre Navidad y el Carnaval: por una parte la preeminencia de lo burlesco, la violencia ritual, el goce por la inversión de roles y el desenfreno festivo, interpretado por los estudiosos mayoritariamente como esparcimientos profanos combatidos por la Iglesia; por otro el origen pagano de esta lógica cómico-festiva, contraria al parecer a la sensibilidad religiosa cristiana. Como consecuencia de los resultados obtenidos en una investigación histórica y antropológica sobre la comicidad en los rituales y fiestas navideños en Andalucía, ${ }^{1}$ creemos que esta doble consideración, ampliamente extendida entre los investigadores de la fiesta, merece una seria revisión. Fue por un lado la lectura de la vasta obra de Julio Caro Baroja y por otro la indagación sobre el sentido religioso que ciertas personas y grupos, clérigos y laicos, asignaban a estas polémicas fiestas, lo que nos puso sobre la pista para estudiar la religiosidad de la risa navideña, no solo en cuanto a práctica de creyentes, sino en cuanto a discurso teológico. Hace años que Caro Baroja (1979: 59-67) escribía

${ }^{1}$ El proyecto de investigación Saturnalias Andaluzas (2005-2008) fue financiado por la Consejería de Cultura de la Junta de Andalucía, a través de su programa de subvenciones a proyectos para la realización de actividades etnográficas. La metodología utilizada en la investigación (con observación directa, entrevistas semiestructuradas, encuestas y trabajo documental archivístico), así como los principales resultados etnográficos fueron expuestos en sendas Jornadas de Etnología celebradas en Sevilla y en Huelva, en 2006 y 2009 respectivamente. 
sobre la necesidad de reconsiderar ciertas generalizaciones sobre la religiosidad popular, dadas por buenas acríticamente, como la tendencia de antropólogos, historiadores y folcloristas a ver en nuestras fiestas supervivencias de antiguos cultos paganos. "Lo que aún existe en el fondo de los campos no es tanto una supervivencia de viejos sistemas religiosos, lozanos en un tiempo, como una serie de nociones que pueden vivir adheridas al Cristianismo o enfrentadas a él sin que, por fuerza, dependan de un mundo religioso pasado correspondiente a una sociedad desaparecida hace siglos" (Caro Baroja, 1979: 60). Consideraba el maestro de la etnología española que la relación entre las fiestas populares y los cultos grecorromanos no era tanto de orígenes históricos sino de semejanza funcional: unas y otros cumplían fines múltiples y coincidentes. Achacaba Caro Baroja la divulgada aceptación de la hipótesis de las supervivencias paganas, a un insuficiente énfasis en la indagación histórica, algo que reiteraba en Las formas complejas de la vida religiosa (1985).

Queremos retomar aquí las advertencias de Caro Baroja, expuestas en diferentes obras (1965: 12; 1979: 59-67; 1985: 347-348), para indagar en el sentido religioso de la alegría navideña y más en concreto en la justificación antropológica y teológica de ciertas diversiones jocosas habitualmente consideradas carnavalescas. Argumentaremos aquí que la risa, la subversión ritual y, en general, el gozoso desenfreno de hechos y palabras en ciertas fiestas invernales, y muy especialmente en las que se celebran en torno a la Navidad, no constituyen un ingrediente ajeno a la teología y la religiosidad cristiana, sino antes bien han formado parte consustancial, al menos entre ciertos grupos de cristianos, de la manera de vivir un momento clave en el ciclo ritual. Centramos este texto en el análisis de cómo una parte del estamento clerical ha justificado, promovido y alentado las mismas celebraciones que las que el sector más ortodoxo de la Iglesia consideraba escandalosas, irreverentes, pecaminosas, cuando no supervivencias paganas y diversiones del demonio, para comprobar que esta sensibilidad cómico-festiva ha tenido - y sigue teniendo- un hondo sentido religioso para algunos creyentes, clérigos y laicos.

\section{LA HIPÓTESIS DEL ORIGEN PAGANO Y EL CARÁCTER PROFANO DE LAS FIESTAS BURLESCAS NAVIDEÑAS}

El carácter burlesco de muchas de las fiestas populares del ciclo invernal, y más en concreto de las celebradas entre Navidad y Reyes, está fuera de toda duda (Amades, 1950; Caro Baroja, 1965; Gaignebet, 1984; Satrústegui, 1988; Del Campo, 2006, 2008) y se concreta en prácticas humorísticas como cantar coplas o villancicos más o menos graciosos en cuadrillas itinerantes que piden el aguinaldo; armar ruido con cencerros, vejigas, látigos; gastar bromas como robar o cambiar de 
sitio macetas o animales domésticos; disfrazarse grotescamente como bestia, ser monstruoso, diablo o bien a la manera cómica de arlequín, inocente; escarnecer y ridiculizar a los vecinos mediante pregones de ánimas o testamentos jocosos de fin de año; sacudir el orden jerárquico tomando el pelo a los poderosos, obligándoles a someterse a una autoridad festiva, a la que tienen que obedecer efímeramente; y en general, todo tipo de desenfreno festivo, con particular énfasis en lo cómico y la inversión de roles. En Andalucía, como en cualquier otra parte de España, hay buenas muestras de este tipo de fiestas, especialmente en los días comprendidos entre el 24 y el 28 de diciembre, aun si han declinado notablemente en las últimas décadas, llegando algunas incluso a desaparecer: cuadrillas que cantan villancicos y coplas burlescas (pandillas de mochileros de algunas localidades del valle del Genil, pandas de catetos en los montes de Málaga, parrandas de troveros alpujarreños, pastorales de los cortijos de Mijas), fiestas de Inocentes y Ánimas (como los cascamorras o cascaborras de Guadix, Baza o Puebla de Don Fadrique en la provincia de Granada); danzas de locos como las de Fuente Carreteros (Córdoba); representaciones teatrales pastoriles en las que muy frecuentemente se mezcla lo profano y lo sagrado, lo chabacano y lo solemne como los retablos que se hacían en algunos pueblos de Los Pedroches (Córdoba).

Ciertamente, en toda Europa y desde la Antigüedad, los doce días comprendidos entre la Navidad y la Epifanía se han caracterizado por aglutinar diferentes costumbres lúdricas, que se han englobado usualmente como muestras de las "libertades de diciembre" o las "locuras de enero". La referencia a las libertates decembricae de Horacio no es azarosa, pues igualmente desde los primeros siglos del cristianismo, teólogos y laicos, denostadores y simpatizantes de estas prácticas, historiadores, folcloristas, antropólogos, las han explicado frecuentemente como reminiscencias paganas — vinculadas a las Saturnales romanas y las Kalendas de enero-, que el cristianismo nunca habría podido extirpar del todo, y que, en cualquier caso, estaban en las antípodas de la liturgia y las celebraciones pías, más cercanas al decoro y la solemnidad que exigía el misterio del nacimiento de Cristo. A finales del siglo IV, cuando aún se celebraba la Natividad el 6 de enero en el Oriente cristiano, San Juan Crisóstomo ya denunciaba las mascaradas, comedias y coros de los primeros días del año (In Kalendas, PG XLVIII, 953-962). Entre el siglo IV y V otros Padres y doctores de la Iglesia pusieron el grito en el cielo por las impías celebraciones de las Kalendas. De ello se quejaba San Ambrosio ("Qui Kalendas lanuarias colit, peccat", sermón XVII, Increpatio de Kalendis lanuariis), San Agustín (Sermo CXCVII de Calendiis Januariis contra Paganos, PL, XXXVIIII, 1024-1026) o San Máximo de Turín, quien censuraba que el pueblo se disfrazara de mujer, animal o seres fantásticos, algo que también denunciaba el obispo de Rávena, San 
Pedro Crisólogo. ${ }^{2}$ Que especialmente los rústicos, aun después de cristianizados, seguían con costumbres y creencias paganas en torno a estas fechas, resultaba evidente a Martín de Braga. El que presidiera el segundo concilio de Braga en el año 572, denunciaba en su Sermón contra las supersticiones rurales (De correctione rusticorum), los "inventos del demonio" que mantenían los campesinos de Galicia. A pesar de las reiteradas censuras eclesiásticas, el pueblo mantuvo infinidad de creencias y prácticas festivas en torno al inicio del año, como demuestra que en el año 960 Burcardo de Worms siguiera lamentándose de unas costumbres que los teólogos consideraban herencia de los romanos. ${ }^{3}$

Durante toda la Edad Media continuaron celebrándose la última semana del año y la primera del siguiente, diversiones como las conocidas como festa stultorum o fatuorum (fiestas de locos). A pesar de que en gran medida constituían fiestas clericales (Heers, 1988; Prévot, 2004), protagonizadas por subdiáconos y otros escalafones inferiores de la jerarquía eclesiástica (de ahí que también recibieran el nombre de festa subdiaconorum), la mayoría de escritores eclesiásticos - como el obispo de Auxerre en 1220 - siguió interpretando estas fiestas licenciosas como supervivencias paganas. ${ }^{4}$ De eso mismo estaba convencido, siglos más tarde, fray Bartolomé de las Casas al hablar de ciertas costumbres como las estrenas y aguinaldos "en los días de Navidad hasta la Epifanía", que vinculaba a las fiestas dedicadas por los romanos a Saturno, por lo que las de su época no eran más que "el vestigio y restos de aquellas fiestas [las paganas] entre los cristianos" (Casas, 1909: 437). Más tarde Sebastián de Covarrubias, en su Tesoro

2 "Abstrahat ergo pater filium, servum dominus, parens parentem, civem civis, homo hominem. Christianus omnes qui se bestiis compararunt, exaquarunt jumentis, aptaverunt pecudibus, daemonibus formaverunt" (Sermo CLV de Kalendiis Januariis, quae varia gentium superstitione polluebatur, PL, LII, 609-611).

3 “¿Has celebrado las calendas de enero según la usanza pagana, haciendo con ocasión del año nuevo algo más de lo que solías hacer antes o después, disponiendo ese día en tu casa la mesa con lámparas y platos diversos, cantando y danzando por calles y plazas; o te has sentado en el tejado de tu casa dentro del círculo trazado a tu alrededor con un cuchillo, a fin de prever lo que te ocurriría el año siguiente? ¿Has ido a la bifurcación del camino y te has sentado sobre una piel de toro para adivinar el futuro; o has puesto a cocer esa noche hogazas con tu nombre, convencido de que si se ponían altas y apretadas, el nuevo año te traería una vida feliz?" (Burcardo de Worms, Decretorum libri XX: PL 140, 960, apud Giordano 1983: 185).

4 "Se me pregunta por qué en este día se hace la fiesta de los locos: antes de la venida del Señor, se celebraban las fiestas llamadas Calendas, que la Iglesia quiere abolir por ser contrarias a la fe; pero como no las puede extirpar complemente, permite y celebra esta fiesta (la Circuncisión de Jesús) para que la otra caiga en desuso" (Massip, 1992: 26). 
de la Lengua Castellana o Española de 1611, equiparaba el Antruejo a las Carnestolendas, especificando que "en algunas partes lo empiezan a solemnizar desde los primeros días de enero", lo que era síntoma inequívoco de que "tienen un poco de resabio a la Gentilidad y uso antiguo, de las fiestas que llamaban Saturnales, porque se convidaban unos a otros, y se enviaban presentes, hacían máscaras y disfraces, tomando la gente noble el trage vil de los esclavos, y los esclavos por ciertos días eran libres y no reconocían señor" (Covarrubias, 1995: 98).

Las comparaciones con aquellas fiestas romanas, en que incluso los esclavos eran libres efímeramente, partió de la lectura de autores como Macrobio (siglo IV), fuente indispensable para el conocimiento del mundo antiguo, y autor muy estudiado por los clérigos a finales de la Edad Media. Vincular las fiestas clericales de tinte burlesco con las que hacían los paganos, parecía inevitable, pero en modo alguno constituía una operación inocente, pues así se denigraba a los que encontraban en estos desenfrenos un acomodo, aunque heterodoxo, a la teología cristiana. Desde el Renacimiento en adelante, no solo no mermó la creencia de que las Saturnales y las Kalendas constituían las fuentes de los juegos alocados entre Navidad y Reyes, sino que, en parte por la fascinación hacia la Antigüedad y, más tarde, por la Reforma protestante, se generalizó la hipótesis del origen pagano de diferentes costumbres festivas y burlescas que se desparramaban en otras fechas entre diciembre y febrero: San Nicolás (6 de diciembre), Santa Lucía (13 de diciembre), San Esteban (26 de diciembre), San Juan Evangelista (27 de diciembre), Santos Inocentes (28 de diciembre), San Silvestre (31 de diciembre), Circuncisión (1 de enero), Epifanía o Reyes (6 de enero), San Antón (17 de enero), San Sebastián (20 de enero), la Purificación o la Candelaria (2 de febrero), San Blas (3 de febrero) y Santa Águeda (5 de febrero). El sacerdote y arqueólogo Rodrigo Caro relacionaba en sus Días geniales o lúdricos, escrito en 1625, las costumbres saturnalicias romanas ("dar voces como locos, jugar, hacer reyes, combidar a los esclavos, cantar y vaylar desnudos...") con los "disparates" que hacían los rústicos en las aldeas durante la fiesta de los Inocentes, como el ponerse "carátulas" y echar "coplas de repente" (Caro, 1978, II: 210). En Francia, Monsieur du Tillot, gentilhombre ordinario de su Alteza Real el duque de Berry, no dudaba en su Mémoire sur la Fête des Fous, escrito en 1751, de que aquellas extravagantes fiestas, "derivadas casi todas ellas del paganismo e introducidas en tiempos poco ilustrados", se debían a la "ignorancia y la barbarie de los fieles que precedieron al renacimiento de las Bellas Letras en el siglo XVI en Italia, de donde pasaron a las demás partes de Europa" (apud Heers, 1983: 5). Pensaba Du Tillot que "los Cristianos hicieron retroceder las Saturnales hasta las fiestas de Navidad, que eran un tiempo de regocijo a causa del nacimiento del Salvador, y que las hicieran durar hasta el primer día de enero" (apud Heers, 1983: 22). Por su parte, Jean-Paul (1763-1825), que 
había estudiado teología antes de dedicarse a la literatura, reconocía que "fue precisamente en los tiempos de mayor fervor del catolicismo cuando se celebraron las fiestas de locos y del asno, la representación de misterios y sermones burlescos del domingo de Pascua", pero se equivocaba al pensar que "entonces, en efecto, las cosas respetables jamás se confundían con semejantes mascaradas y se diferenciaban entre sí de una manera tan tajante como el Sócrates de Jenofonte se diferencia del de Aristófanes" (Jean-Paul, 1836: 18-19).

Después de La Rama Dorada de Frazer, los folcloristas del siglo XIX y aun, en el XX y XXI, los historiadores y antropólogos han aceptado mayoritariamente la hipótesis de la herencia pagana y el carácter eminentemente profano de unas prácticas, que en los últimos dos siglos se han concentrado en contextos festivos populares, aunque nunca se han secularizado del todo, manteniéndose en ambientes clericales y conventuales, en donde aún hoy se celebran autos jocosos, se cantan villancicos más o menos risibles o los monjes se gastan bromas el día de los Inocentes. En la actualidad, el hecho de que muchas de las fiestas burlescas del ciclo de Navidad se celebren aún bajo un marco religioso, no impide que prosiga la tendencia generalizada entre los estudiosos de tildar dichas fiestas de extra-religiosas 0 incluso antirreligiosas, interpretando que las instituciones que las amparan —las cofradías de ánimas, por ejemplo_ no son más que "el marco legal que es aprovechado por personas poco religiosas para impulsar sus fiestas", de tal manera que "la fiesta aparece enmascarada bajo la apariencia religiosa para poder subsistir" (Ciudad, 1987: 294-295).

Sin duda la abundante documentación censuradora a lo largo de los siglos en tratados teológicos, concilios, sínodos, visitas pastorales y sermones, en los que estas fiestas eran etiquetadas como frutos del diablo y herencia del paganismo, ha inducido a considerarlas exclusivamente diversiones profanas, a las que se habrían apegado, aquí y allá, los sectores más dubitativos y heterodoxos de la clerecía, así como el pueblo que se servía tales días de un barniz religioso para desatar la locura festiva. Sin embargo, y pese a la contundencia de los testimonios, creemos que esta generalización encierra un reduccionismo simplificador. No parece discutible la provechosa estrategia cristiana de situar sus celebraciones en los mismos días festivos que los paganos; sabido es que el nacimiento de Cristo, del sol divino, se hizo coincidir con la celebración del dies natalis invicti solis romano. Se aprovechaba así una misma temposensitividad cíclica y bipolar (Del Campo, 2006), unas mismas simbologías, sentimientos, emociones y sentidos para cada época del año, especialmente atendiendo al ciclo agrario del campesinado en el que influían notoriamente los cambios astronómicos y meteorológicos: la sucesión de días largos o cortos, fríos o calurosos, los solsticios y equinoccios, los momentos de cosecha o carestía, etc. 
Resulta igualmente evidente que la Iglesia llevó a cabo durante siglos una estrategia de asimilación, adaptación, apropiación y resemantización de prácticas que no podía o no quería desterrar. Clásica es ya la cita del papa Gregorio Magno [590-604] cuando escribe a los misioneros de los anglos ofreciéndoles directrices para una eficaz evangelización:

No se deben destruir los templos paganos de los pueblos, sino únicamente los ídolos que se encuentran en su interior. Se bendecirá agua bendita y con ella rocíense los templos. Constrúyanse altares y deposítense en ellos las reliquias [...]. Y puesto que solían sacrificar muchos bueyes a los espíritus malos, es necesario conservar, modificada, esta costumbre también, haciendo un convite, un banquete, con mesas y ramas de árbol puestas alrededor de las iglesias ("Epist. 76 ad Mellitum Abbatem", en $P L 77,1215)$.

Estas formas de adaptación han sido bien estudiadas con rigor e imaginación por historiadores de la religión, como Mircea Eliade u Oronzo Giordano, y forman parte hoy del acervo de conocimientos comunes de una persona medianamente instruida. Y sin embargo, una cosa es rastrear paralelismos indiscutibles entre prácticas festivas de distintos siglos, elementos de continuismo y sincretismo en el paso de una religión a otra, y cuestión distinta pretender que dichas locuras festivas fueron y son un elemento ajeno a las convicciones y creencias cristianas, como si estuvieran, por así decirlo, superpuestas a las auténticas manifestaciones de fe y religiosidad cristiana. Una cosa es comprobar que algunos o muchos de los que participan en estas fiestas lo hacen sin ningún tipo de sentido religioso, y otra afirmar que la fiesta en sí carece de sacralidad, incluso es en su exaltación de goce y comicidad contraria a la religión. Esta concepción adolece, a nuestro parecer, de ciertas inexactitudes, todas ellas íntimamente vinculadas entre sí:

1. Aunque se suele reconocer la mezcolanza entre prácticas y teologías paganas y cristianas, los antropólogos sociales (que son los que mayoritariamente han estudiado las fiestas populares) no siempre abordan con rigor el sentido de la aportación cristiana, ignorando los escritos teológicos, las prácticas y discursos religiosos (como los sermones) que durante siglos han contribuido a moldear, interpretar y enjuiciar las formas de devoción y festividad en torno a la Navidad. Otro tanto ocurre entre los investigadores de las diversiones clericales. Se atribuye así cualquier manifestación risible, burlesca, escandalosa, a la herencia pagana, como si se tratara de un fruto irreverente, una manzana podrida que la Iglesia no habría podido extraer del cesto ortodoxo. Y sin embargo, cuando decimos que las fiestas navideñas se caracterizan por una profusión de prácticas que tienen en común una particular manera 
de entender la alegría festiva, no podemos olvidar que la Iglesia -más que nadie - ha reflexionado sobre qué tipo de laetitia o gaudium debía primar en lo que para el creyente - no se olvide- es el principal misterio, junto con la Resurrección. Si el severo teólogo Jean Belethus, refiriéndose en el siglo XII a la fiesta de locos, la califica de confusum officium y tripudium, el investigador debe analizar -como hace, por ejemplo, Arlt (1970: 40)— qué sentido tenían esos términos, si quiere conocer con qué ojos se miraban entonces esas prácticas festivas. Y lo mismo cabe decir sobre cómo se pronuncia hoy la Iglesia al hablar de dichas fiestas, y qué interpretación merecen especialmente a los sectores clericales más cercanos al pueblo.

2. Es práctica habitual, en este sentido, tratar el cristianismo de manera homogénea, así como el estamento clerical. A lo largo de la historia, y la actualidad no es una excepción, han coexistido en el seno de la Iglesia múltiples maneras de interpretar los más variados aspectos de la religiosidad, incluyendo la liturgia y la particular concepción del dies festus. A veces se pasa por alto que la jerarquía eclesiástica estigmatizó, hasta declararlas herejías, las doctrinas que atentaban contra sus bases principales, pero no tanto sus prácticas, en las que nunca se pudo llevar a cabo la pretendida uniformidad, especialmente si las seguían grupos de clérigos con un amplio apoyo popular. Igual que hoy no piensa, ni escribe, ni actúa igual un párroco afín a la Teología de la Liberación que trabaje en una comunidad de los Andes, que un miembro conservador de la Conferencia Episcopal Española, nunca ha existido en el seno de la Iglesia una contundente homogeneidad, como ocurre por otra parte en cualquier institución. Naturalmente - se argumenta a veces- los que han marcado la historia han sido unos (los que han ostentado el poder) y no otros. Pero esto no es óbice para que encontremos a lo largo de la historia prácticas controvertibles en el seno de la Iglesia, como demuestran no solo las actuaciones disidentes y críticas de muchos eclesiásticos de la periferia, sino también el comportamiento de los que han ocupado la cúspide de la jerarquía católica, incluyendo a obispos y al propio Papa, los cuales han participado muchas veces -como en seguida veremos- en fiestas que resultaban problemáticas.

3. El tercero de los elementos, apriorísticamente aceptados, que nos parece discutible, radica en vincular automáticamente la hipótesis de la herencia pagana con la supuesta irreligiosidad de esas prácticas. La fuente más importante de la que se nutre esta consideración es la prolija documentación eclesiástica que, al menos desde el siglo IV, tilda dichas fiestas simultáneamente de paganas e impías, como si las auténticas manifestaciones religiosas fuesen puras, no contaminadas con elementos de otras religiones. La evidencia, sin embargo, demuestra que 
prácticas como la medieval fiesta del asno (festum asinorum) ${ }^{5}$ la fiesta de locos (festum stultorum o fatuorum) o versiones de estas como la francesa fiesta del báculo (festum baculi) o la fiesta del obispillo (episcopus puerorum), muy divulgada en el contexto peninsular, constituían fundamentalmente regocijos clericales en los que participaba a menudo el propio obispo y los mandatarios más respetables de la diócesis. Naturalmente, en las mismas fechas en que se celebraban con la aquiescencia de ciertos clérigos, se censuraban como impías en los concilios y las condenaban otros teólogos, como hizo por ejemplo Inocencio III con las fiestas clericales entre Navidad y los Inocentes. ${ }^{6}$ Pero esto no es más que una muestra de una Iglesia con múltiples y contradictorias caras, como precisamente con respecto a este tipo de fiestas puso de relieve Caro Baroja (1965: 12). De la misma manera, el sentimiento religioso que muchos laicos experimentan hoy en algunas de estas fiestas burlescas no parece en absoluto contradictorio con su carácter lúdico y risible. A veces da la sensación que esto constituye una paradoja insalvable para el investigador, que prejuzga y clasifica sin tener en cuenta la vivencia, incluso los discursos de los actores, los cuales sí

${ }^{5}$ En esta, los clérigos entraban en el templo en una procesión que presidía un asno, mientas se entonaba el conductus asini (conducto del asno), en el cual se ensalzaba el asno de Isachar, mientras se repetía el estribillo "hez, hez, sir asne, hez". Véase Heers (1988) y Arlt (1970). Para el simbolismo del asno, incluyendo su uso ritual y festivo, me remito al Tratado del burro y otras bestias (Del Campo, 2012).

${ }^{6}$ En respuesta a unos obispos de Gnesen (Polonia), que consultaban al Papa sobre la licitud de ciertas fiestas clericales, la censura de Inocencio III no deja lugar a dudas y pasaría después a las sumas canónicas de la Compilatio Tertia y a las Decretales de Gregorio IX (1234): "A veces se celebran, en las propias iglesias, juegos teatrales, $y$ no solo se introducen mascaradas monstruosas, con fines de escarnio, sino que también, en los tres días festivos que siguen a la Navidad de Cristo, los diáconos, presbíteros y subdiáconos, por turnos, ostentando las extravagancias de su propia locura, degradan el decoro clerical con gesticulaciones y obscenas exaltaciones en presencia del pueblo" ("Ludi theatrales etiam praetextu consuetudinis in ecclesiis vel per clericos fieri non debent. Quum decorum domus Dei. Interdum Iudi fiunt in eisdem ecclesiis theatrales, et non solum ad ludibriorum spectacula introducuntur in eis monstra larvarum, verum etiam in aliquibus anni festivitatibus, quae continue natalem Christi sequuntur, diaconi, presbyteri ac subdiaconi vicissim insaniae suae ludibria exercere praesumunt, per gesticulationum suarum debacchationes obscoenas in conspectu populi decus faciunt clericale vilescere, quem potius illo tempore verbi Dei deberent praedicatione mulcere. Quia igitur ex officio nobis iniuncto zelus domus Dei nos comedit, et opprobria exprobrantium ei super nos cadere dignoscuntur, Fraternitati vestrae per apostolica scripta mandamus, quatenus, ne per huiusmodi turpitudinem ecclesiae inquinetur honestas, eos, etc. praelibatam vero ludibriorum consuetudinem vel potius corruptelam curetis a vestris ecclesiis taliter exstirpare, quod vos divini cultus et sacri comprobetis ordinis zelatores" (Friedberg, 1878-1881: 452). 
parecen lidiar bastante bien con unos binomios que solo en apariencia resultan contradictorios: devoción-diversión, sacralidad-risa, degradación burlesca-exaltación de la fe.

4. Finalmente creemos que en ocasiones se abusa de la generalizada tendencia a dar por supuestos vínculos culturales comunes cuando observamos costumbres semejantes en otros pueblos, como si solo pudieran explicarse por préstamos o difusión cultural, es decir, como consecuencia del contacto entre culturas. Hace tiempo que Claude LéviStrauss demostró cómo ciertos patrones culturales estaban extendidos entre sociedades sin influencias recíprocas. En "el desdoblamiento de la representación en el arte de Asia y América", publicado originariamente en $1944,{ }^{7}$ comparaba las evidentes analogías entre las artes de la costa noroeste de América y de la China arcaica o de la de los pueblos de Nueva Zelanda, a pesar de que los maoríes nunca pudieron llevar sus ornamentos a la costa del Pacífico. Si la historia demostraba que no había podido existir difusión cultural —alegaba Lévi-Strauss-, había que volverse hacia otras disciplinas, la psicología o el análisis estructural, para preguntarse si no existían conexiones internas, de naturaleza psicológica o lógica, que permitieran comprender recurrencias simultáneas que tienen lugar con una frecuencia y cohesión que ni pueden resultar del simple juego de probabilidades, ni son achacables al contacto entre culturas diferentes. Sin apelar al subconsciente colectivo ni a inverificables hipótesis estructuralistas, Caro Baroja $(1965,1985)$ ha demostrado, con la evidencia histórica, la particular manera mitopoética de dar sentido al tiempo vivido por el campesinado, con una concepción dramática de la existencia en que se entretejen conjuntamente la naturaleza, el hombre, la sociedad y Dios, conforme a una vivencia común a muchos pueblos de similar relación con el entorno.

\section{LA ALEGRÍA ESPIRITUAL}

La primera y segunda tendencia explicativa están íntimamente vinculadas. No se suele abordar la visión teológica que sí da sentido a las fiestas risibles navideñas, porque es mucho más significativa y visible la cara más censuradora y seria de la Iglesia, la de la pastoral del miedo (Minois, 2005: 199 y sigu.), esa que permitió con instituciones como la del Purgatorio administrar la salvación doctrinalmente. A pesar de que la represión de la risa, especialmente entre los clérigos, ha sido una de las principales preocupaciones de la Iglesia (Le Goff, 2006: 163), desde hace algún tiempo se vienen sacando a la luz argumentos que demuestran cómo la Iglesia - 0 , si se prefiere, una parte de la Iglesia- no siempre ha censurado la lógica burlesca en multitud de manifestaciones

7 Incluido posteriormente en Antropología estructural (Lévi-Strauss, 2000: 263-292). 
expresivas. El libro de José Emilio Burucúa (2001) sobre la sacralidad y la risa entre los siglos XV a XVII o los estudios de Martha Bayless sobre los géneros cómicos medievales, son solo un par de ejemplos. En Parody in the Middle Ages (1996), Bayless analiza himnos, misas, vidas de santos, narraciones bíblicas y otras creaciones literarias paródicas, muchas de las cuales no solo hacen burla de ideas religiosas, sino que fueron escritas, divulgadas y conservadas por clérigos. En nuestro contexto, no hay más que recordar al clérigo Juan Ruiz, arcipreste de Hita, que no tiene empacho en el Libro de Buen Amor de ridiculizar los usos litúrgicos en su relato alegórico de la batalla entre don Carnal y doña Cuaresma. Estos testimonios y estudios desmontan una visión muy divulgada, derivada de una lectura excesivamente simplista de los estudios de Bajtin (1987), y que ve un abismo entre la cultura clerical oficial, seria, solemne, tenebrosa, y la popular, dada a la subversión carnavalesca. Demuestran por un lado la multiplicidad de sentidos de las creaciones cómicas (parodia, sátira, pasatiempo lúdico, pero también resemantización doctrinal con lenguajes propios de otros grupos subalternos), y por otro que la comicidad carnavalesca no supone siempre y simplemente el revés, la otra cara de la moneda, de la cultura seria, eclesiástica. La burla y la risa no han sido nunca privativas de ambientes profanos y populares. Es más, frente a la concepción clerical dominante de la maldad de la risa, habida cuenta de que Cristo nunca había reído, ha convivido con más o menos dificultades según las épocas, la visión sagrada del regocijo, especialmente propicia en la celebración de los misterios.

La Iglesia acogió la temposensitividad clíclica y bipolar que asignaba en el ciclo litúrgico y festivo momentos de alegría y tristeza, recogimiento y júbilo, esperanza y zozobra, acorde con los ritmos que la naturaleza imprimía en el hombre apegado a la tierra, y muy especialmente con su quehacer agrícola y ganadero cambiante. "Es absurdo —escribe fray Luis de Granada (1504-1588)_, cuando todas las aves se adaptan a los tiempos y en razón de ellos cambian de lugar, que nosotros no queramos o no sepamos atenernos a los tiempos litúrgicos que la Iglesia establece para bien de nuestras almas" (Granada, 1999: 95). Igual que los cuerpos, también el alma necesitaba de mudanza y variedad, y así "la Iglesia, que como madre piadosa está siempre atenta a nuestras necesidades, se da cuenta de ello y dedica momentos diferentes del año no sólo para evitar con esa misma variedad el tedio por las cosas espirituales, que nos podría haber perjudicado mucho, sino además para proporcionarnos materia de virtudes variadas y piadosos afectos" (ibídem 95).

Para el cristianismo, la estancia en la tierra no es más que una sucesión de trabajos y penas, que tiene como fin la salvación en la fiesta eterna. Sin embargo, los momentos cenitales del ciclo festivo -la Pascua 
del nacimiento de Cristo y la de su Resurrección- fueron interpretados por algunos segmentos clericales como los momentos propicios en los que manifestar esa alegría desbordada que habría de regir cuando nazcamos de nuevo o renazcamos después de la muerte en la eternidad. De la misma manera que el cristiano no debía mostrar un exceso de pena ante la muerte, dado que suponía una actitud de incredulidad ante el más allá, no solo podría sino debería regocijarse ante el nacimiento y el renacimiento de Cristo, porque mostraba así su esperanza por alcanzar la gloria eterna. Naturalmente la doctrina hegemónica recomendaba el aprovechamiento espiritual de esa alegría festiva, de ahí que recomendara un goce íntimo de oración y actos piadosos. Y en gran medida hacía hincapié en que la Navidad no solo celebra la primera llegada del Cristo hecho hombre para salvarnos, ni la presente y diaria estancia del Cristo bondadoso y misericordioso entre las almas de los justos, sino también celebra la segunda llegada del Dios que vendrá a juzgarnos. La Iglesia, decía fray Luis de Granada en un sermón de Adviento, nos pide "que seamos agradecidos con Dios Salvador, nos pide amor, piedad, y el obsequio de un espíritu devoto" (Granada, 1999: 95). Había que celebrar con la Navidad la venida de Dios al mundo; era lícito regocijarse, pero con piedad, no de manera indecorosa. Como la mayoría de teólogos, el dominico granadino censuraba como diabólicos los fastos con que la gente pecaba en la celebración de la Navidad. Con el pretexto de conmemorar la venida de Cristo, se daba rienda suelta a la voluptuosidad, la carne y la risa, cuando debía prevalecer la austeridad, la piedad y el llanto:

Estos son los que esperan el día del nacimiento del Señor solo para comer más, para devorar con insaciable avidez esos gallos que han estado engordando todo el año; para dedicar un día festivo a la glotonería, a la desvergüenza y a la vileza, para entregarse con mayor licencia a los placeres, la diversión, la bebida y las orgías.

[...] Estas son las fiestas de muchos cristianos de hoy, fiestas que ni los judíos de aquel tiempo celebraban así, pues aunque en sus banquetes comían más, lo hacían por imperativo de la ley [...]. Nosotros, no por mandato del Señor, sino por amor a la carne y al placer, convertimos las festividades religiosas en un culto al cuerpo; y para esto las esperamos tan ansiosamente, para comer con más y más avidez, sin ocuparnos de ningún alimento o reparación espiritual; como si viviéramos sólo para la carne, como si sólo de carne estuviéramos hechos, y no tuviéramos ni una chispa de espíritu.

[...] Lo que es más grave, la memoria del nacimiento del Señor, se toma como ocasión para satisfacer la carne. Se preparan 
con sumo interés vestidos lujosos y comidas suculentas, como si Cristo quisiera esto en su natividad y fuera más digno recibirle donde mejores vestidos y comida haya. Pero oye lo que dice él mismo: Tenía mirada soberbia y corazón insaciable: con éste yo no comía ¿Por qué preparas tus vestidos con tanto anhelo para mi nacimiento? Yo detesto la soberbia, no la quiero. ¿Por qué acopias con interés tanta comida para ese día? Yo condeno los placeres de la carne, no los apruebo.

[...] Donde se ve que el demonio, no sólo no teme esta clase de fiestas, sino que se ríe de ellas y casi las desea. De ellas se dice: Viéronla sus enemigos y mofáronse de sus solemnidades (Lm $1,7)$. Pero la Iglesia no se ríe, sino que llora y se lamenta con el profeta: Enlutados están los caminos de Sión; porque ya no hay quien vaya a su fiesta (Lm 1, 4).

Los hombres carnales celebran las fiestas al diablo, no a Dios. Cuando en el natalicio mismo del Señor levantan su mesa, y sobre ella ponen los dados, la suerte, las cartas y luego, mientras juegan, juran y perjuran, y animados por el vino se insultan, se pelean y de vez en cuando ponen en el cielo su boca sacrílega, ¿acaso estos, cuando se comportan así en esta fiesta sagrada, no erigen su altar al diablo?

Esta es la fiesta a la que acuden los hombres carnales, no a la fiesta solemne de Dios. Así no, hermanos; así no se puede celebrar esta festividad, sino con piadosa devoción, con lágrimas, con alabanzas, con alegría espiritual, con acción de gracias y reconocimiento de un beneficio tan grande, con ofrendas espirituales, esto es, con limosnas a los pobres, a los que se debe atender especialmente en este tiempo, los cuales además, cuando muráis, como dice el Salvador, os reciban en las eternas mansiones, en las que estas fiestas temporales se transformarán en gozos eternos (Granada, 1999: 431).

Es fray Luis de Granada nuestro particular y andaluz San Bernardo, con su obsesión por la carne y el pecado en el día de la Navidad. Quería el dominico que atendiéramos especialmente a los pobres, habida cuenta de cómo la Natividad celebraba la llegada de Cristo hecho a sí mismo un pobre mortal, tiritando en el pesebre, como muestra de su compromiso con lo ínfimo. Preconizaba además, como era habitual, que celebráramos la Navidad con lágrimas más que con risas, con acción de gracias y con una alegría espiritual (spiritualis laetitia) como la que recomendaba San Bernardo, igual que mediante el rezo habríamos de beber el vino espiritual (vinum spirituale) que al embriagarnos el alma, nos hiciera olvidar los deleites carnales (S. 
Bernardo, In Cantica, sermo XVIII, 5: PL 182). Al censurar las manifestaciones gozosas de la fiesta navideña, y tildarlas de frívolas, irreligiosas, pecaminosas, diabólicas, fray Luis de Granada se situaba en el sector eclesiástico mayoritario, pero no único. La soberbia, que según el teólogo era una de las fuentes de estas celebraciones que mancillaban el decoro sagrado, había de combatirse con una humildad piadosa. Pero hubo también quien haciendo una singular interpretación de la teología de la humildad aceptaba de buen grado el valor cristológico de algunos actos de inversión, típicos de las fiestas navideñas.

\section{EL OBISPILLO: LA INVERSIÓN DEL ORDEN Y LA HUMILLACIÓN PARA LA HUMILDAD}

Piénsese en la fiesta del obispillo, que arraigó en el contexto de las celebraciones de los Santos Inocentes. Esta versión peninsular del episcopus puerorum o episcopellus puede tomarse como una de las variantes de las fiestas de locos medievales. A partir del siglo XII los Ordinarios se hacen eco muchas veces de la festum Innocentum o festum puerorum Innocentum, protagonizada por los niños del coro de las catedrales, uno de los cuales tomaba efímeramente el lugar que ocupaba normalmente el obispo, invirtiendo el orden al que los de abajo estaban confinados en una sociedad adultocéntrica y jerárquica. Se remarcaba así, desde la propia Iglesia, la elección de Cristo por los niños, inocentes, desamparados, débiles, pobres, locos. Inserto en la tradición de autoridades burlescas y reinados ${ }^{8}$ (Caro Baroja, 1965: 336-344; Le Roy Ladurie, 1980: 175-228), típica de las fiestas carnavalescas navideñas, el obispillo era un mozo de coro que ejercía paródicamente el poder a veces varios días desde San Nicolás ( 6 de diciembre) hasta la fiesta de los Inocentes (28 de diciembre). La clerecía participaba humillándose ante el falso obispo, al que se le permitía incluso a veces protagonizar algún oficio litúrgico. La doctrina de "los últimos serán los primeros" (Mt. 20.16, Mc 10.31, Lc 13.30) y la convicción de que el Señor "pone a los humildes en las alturas" (Job 5.11) se representó en la práctica con infinidad de costumbres burlescas, en las que una parte de la Iglesia veía

${ }^{8}$ Antaño existieron fiestas de reyes o reinados en muchos pueblos de Castilla y León o Galicia, aunque no han desaparecido del todo. Así, por ejemplo, en la frontera entre Zamora y Orense, varias localidades Hermisende, Cádavos, La Mezquita - celebran en los primeros días del año sus particulares reinados, en los que no faltan las bromas, bailes, comilonas, borracheras y personajes grotescos (caretos, zamarreiros) que hacen de las suyas, mientras el rey, con ayuda del virrey (elegidos entre los mozos del pueblo) intentan que la descompostura festiva no se desmadre del todo. También en la festa dos rapazes de Ousilhão, al este de Bragança (Portugal), el párroco corona cada 26 de diciembre (San Esteban) a tres vecinos como rey y vasallos, los cuales, montados en un carro, protagonizan una procesión bufa, dirigida por una turba de horribles y festivos enmascarados. 
una ocasión propicia para demostrar al pueblo su vocación cristológica y su compromiso con la humildad y los desamparados. Un ejemplo paradigmático puede ser la Cornomannia, que se celebraba el sábado in albis en el prado de Letrán, donde el jefe de los sacristanes de las dieciocho parroquias de Roma aparecía coronado de flores. Disfrazado de sátiro era ridiculizado montando en un asno, recibiendo los cánticos burlescos de la Schola cantorum. Ni siquiera el Papa Juan VIII se perdía tal diversión. Por cada corona de flores presentada por los prelados, daba una moneda de oro, hasta que un arcipreste le ofrecía un zorro, que soltaba entre el público provocando la algarabía de los presentes (Strecker, 1964: 900). Eva Castro (1996: 61) ha puesto de relieve que "la fiesta a la que se hace referencia se desarrollaba en el período preparatorio de Pascua y tenía rasgos muy parecidos a la del Obispillo del ciclo navideño".

También guardaban semejanzas con el obispillo ciertos ritos de paso clericales, como los desordenados festejos organizados para honrar al misacantano en su primera misa, sobre los que hemos reflexionado en otro lugar (Del Campo, 2009). La inversión de roles típica de las fiestas invernales, junto con el marcado igualitarismo simbólico y la alegría festiva, casaban bien con las dramaturgias rituales que destacaban la humillación del iniciado, en parte para escenificar la necesaria humildad a la que estaban obligados los que seguían el ejemplo de Cristo. Así, en el ritual y la fiesta que acompañaban la misa nueva, el misacantano era humillado enharinándole la cara y paseándole en un burro, igual que hacía la Inquisición con los reos, tal y como puede leerse en varias recreaciones literarias del siglo XVI. Por la misma época que fray Luis de Granada —mediados del siglo XVI-Cristóbal de Villalón (1982: 376393) satiriza las costumbres burlescas clericales con ocasión de las misas nuevas (banquetes, borracheras, espectáculos juglarescos, coplas indecentes) y presenta, como también hiciera Juan de Arce de Otálora (1995, II: 1344-1375) en Los coloquios de Palatino y Pinciano (también de mediados del siglo XVI), a un misacantano que ha de soportar un trato vejatorio y burlesco. Juan de Arce asimila los agravios burlescos de los clerizones para con el misacantano, a los que se permiten en la fiesta del obispillo: "En tan solemne fiesta como ésta tienen licencia [los clérigos] de hacer cualquier burla, con tal que no sea muy pesada", pues "ésta es como fiesta del Día de los Inocentes, donde pasa todo y los más ruines mandan más" (Arce, 1995, II: 1355-1356). Tampoco a Cristóbal de Villalón se le escapa la justificación teológica que tendrían estos actos de humillación: imitar la humildad de Cristo para evitar la soberbia del homenajeado.

En el entretanto que estas cosas se celebraban pensaba yo otras muchas: lo primero que consideraba era que aquel nuevo ungido por saçerdote representaba al verdadero Cristo, saçerdote 
eterno según el orden de Melchisedech, y allí en aquel mal tratamiento se me representó todo el que [Cristo] padeçió por mí en sus vituperios, injurias y tormentos, en tanta manera que no me pude contener sin llorar, y dolíame mucho porque era tanta la çeguedad de aquellos vanos saçerdotes que sin templança alguna proseguían en aquella vanidad con tanta disoluçión, perdida la magestad y reverençia debida a tan alta dignidad y representaçión de nuestro Dios; y para alguna consolaçión mía pensé ser aquello como vexamen de doctor, porque aquel nuevo saçerdote no se ensoberbezca por ser de nuevo admitido a tal alta dignidad (Villalón, 1982: 392).

Sin duda era la Navidad uno de los momentos propicios para exaltar la humildad a través de la humillación del poderoso, incluyendo a los propios dignatarios eclesiásticos, que en tal día debían encarnar como el propio Cristo- al hombre pobre, simple, mancillado. "La humillación es camino para la humildad" (Humiliatio ad humilitatem via est), decía San Bernardo (Epist. 77, 11; PL 182, 217). Mientras los concilios y sínodos denunciaban las descomposturas y deshonestidades en el día de los Inocentes, ${ }^{9}$ igual que hacían con las misas nuevas y otras fiestas clericales, la fiesta del obispillo recibía la aceptación de muchos obispos, que delegaban ese día simbólicamente su lugar a un escolar, al cual servían con humildad y humillación, al igual que los santos de los que se decía, con frecuencia, que degradándose como un siervo habrían humillado no solo el alma, sino también el cuerpo. ${ }^{10}$

De la ambivalencia de esta fiesta, se hace eco una biografía de fray Hernando de Talavera, publicada en 1557, probable versión de otra de 1507 escrita por Alonso Fernández de Madrid, familiar de fray

${ }^{9}$ Por poner algún ejemplo, el Sínodo de Juan Bernal Díaz de Luco (Logroño, 1553), ordena que en el día de los Inocentes "se digan las Horas y officios divinos con todo sosiego y honestidad, como se suelen decir en los otros días festivales, y no se de lugar a que se hagan liviandades, ni regoçijos demassiados y deshonestos, y que no se consienta que ese dia prediquen moços de choro, ni otras personas que no sean letrados" (Sínod. de 1553, 286, 18, en García y García, 2007: 336). Otros sínodos, como el de Segovia en 1472, censuraban las "burlas e escarnios e cosas torpes e feas e desonestas" en las fiestas de San Esteban, San Juan Evangelista y Santos Inocentes, "pero por esto non quitamos ni defendemos que non se faga el 'obispillo' e las cosas e abtos a el pertenesçientes, que por çiertos misterios se suelen e acostunbran fazer en cada uno anno" (Sínod. de 1472, 11, en García y García, 1993: 450451).

${ }^{10}$ Eso decía fray Luis de Granada de Santa Catalina de Siena, la cual "se ocupaba en acciones de siervos, ejercía con alegría los oficios de criada, barriendo la casa, lavando los utensilios de la cocina y haciendo otros servicios humildes por el estilo" (Granada, 2004: 35). 
Hernando en Granada. ${ }^{11}$ En el título "Del Obispillo" (cap. XI), el biógrafo incluye una somera descripción de esta fiesta, tal y como se debía de representar en Granada en los siglos XV y XVI. "No dexaré de contar una cosa aunque algunos la juzgaban por redícula y liviana por no saber: y ella era en sí harto maciça y de gran representación y deuoción" (Fradejas, 1996: 459), dice el biógrafo antes de pasar a describir una fiesta, a la que reconoce su antigüedad: "Acostumbrábase antiguamente en las yglesias cathedrales, que el dia del Señor Sant Nicolás elegían de entre los moços de coro un obispillo, cuya dignidad dura hasta el día de los innocentes, que es su propria fiesta" (ibídem 459). El biógrafo de fray Hernando alude claramente al sentido primordial de dicha fiesta, la inversión de roles: "Y entonces se mudan los oficios de los mayores en los menores; y estos mandan y los otros obedecen y son servidos y acatados aquel día los que todo el año andan subjetos sirviendo" (ibídem 459). Esta justificación, enraizada en la doctrina de los últimos serán los primeros, es la que el biógrafo parece querer vincular a la figura del austero fray Hernando, "amigo destas representaciones y cerimonias de la yglesia" (ibídem 459). El arzobispo de Granada —prosigue el biógrafo- "tomaba la cosa tan de veras como a la verdad ella lo debía ser antes quel demonio mezclasse en ello otras vanidades desonestas, que en algunas partes se hazen" (ibídem 459). El Maligno, como siempre, era en última instancia el alentador de las costumbres irreverentes de la fiesta del obispillo, pero por lo demás el biógrafo alaba la actitud de fray Hernando, que se tomaba la molestia en la vigilia de San Nicolás de convocar a los 25 niños del colegio catedralicio, para explicarles las razones que daban un sentido cristiano y honesto a dicha fiesta. Luego realizaba sus consultas entre el cabildo, el rector del colegio y los demás que conocían a los colegiales, para seleccionar entre ellos a aquel que mereciera la dignidad del obispillo. Qué habilidades requería haber demostrado el colegial durante el año, queda claro en los criterios por los que se guiaba al arzobispo: "letras" y "buena conversación", por un lado, y por otro, "humildad" (ibídem 459). El elegido desempeñaba su papel durante los más de veinte días que van de la fiesta de San Nicolás a la de los Santos Inocentes, y obtenía - siempre según el citado autor de la biografía - no poco "provecho temporal", además "del favor y buena reputación que aquel cobraba" (ibídem 459). Ciertamente el obispillo ganaba tales días como un racionero "y se sentaba junto con ellos en su silla y orden" (ibídem 459). El día que conmemoraba la matanza de los Santos Inocentes condensaba el sentido cristiano de esta escenificación de la humildad:

11 Del Sumario de la vida del primer arzobispo de Granada, don fray Hernando de Talavera, y de su gloriosa muerte hay un ejemplar en la Biblioteca Nacional de Madrid (R-13474), que ha estudiado José Fradejas (1966), a quien seguimos. 
Era una cosa que de muchos clérigos se debiera ir a ver el día de los innocentes, el auctoridad con que al obispillo llevaban desde el collegio al coro vestido de pontifical: llevándole la falda el mismo Arçobispo con aquella humildad que el otro se la llevara a él y sirviendo las dignidades y canónigos oficios delos moços y ellos con mucha autoridad muy bien ataviados con ropas y sobrepellizes acompañando a su perlado (ibídem 459-460).

El mundo al revés, en fin, como escenificaban muchas otras fiestas carnavalescas, en las que no estaba implicado directamente el estamento clerical. Los testimonios de los religiosos, cuando son proclives a justificar la fiesta del obispillo, suelen destacar que aquella celebración trascurría con alegría, devoción y humildad, palabras todas que usa el religioso que describe la fiesta granadina en tiempos de fray Hernando de Talavera, como si quisiera alejar toda sospecha de irreverencia y escándalo.

En el tiempo que yo lo vi ninguna representación ni cerimonia ni oficio se fazía en la yglesia que no fuesse muy devota pero esta a mi ver era una cosa de gran edificación y desde el principio de la elección del Obispillo hasta el fin todo traía doctrina y humildad: disciplina y imitación (ibídem, 460).

Para el biógrafo del arzobispo de Granada, el papel que éste jugaba en la fiesta del obispillo engrandecía al dignatario. El que participó en Talavera en diferentes representaciones dramáticas, incluyendo la de "los pastores de la fiesta de Navidad" (ibídem 458), no sólo permitía sino alentaba la fiesta del obispillo para común aprendizaje y exaltación de la humildad, lo cual se escenificaba a través de una humillación y una inversión de roles que el pueblo acogía con regocijo y naturalidad en los días festivos de invierno, propensos a este tipo de carnavalización ritual. "Aun de las cosas que parecían baxas y despreciadas sacaba fructo para todos según el gusto de cada uno" (ibídem 460), alaba el biógrafo del primer arzobispo de Granada. El jerónimo fray Hernando de Talavera, un hombre espiritual, poco amigo de los fastos y el boato, el mismo que censuró a la reina Isabel la Católica por los bailes, las corridas de toros y la conducta deshonesta en ciertas diversiones cortesanas, propiciaba, sin embargo, festejos como el del obispillo, que levantaban en otras diócesis airadas controversias.

Naturalmente los niños del coro no sólo se comportaban con humildad y devoción, como querían los eclesiásticos partidarios de esta fiesta, y en muchos lugares la prohibición fue la consecuencia más drástica. En Toledo, el 5 de diciembre de 1538 —un día antes de la elección del obispillo-, el cardenal Tavera tomaba cartas en el asunto junto con el deán y cabildo de la catedral, después de que estos últimos 
denunciaran los "excesos" que se cometían en la fiesta del "obispillo que dizen de sant nicolas" (López de Ayala y Álvarez de Toledo, 1901: 163165). Si en otros obispados se alaba la humildad y la devoción en el comportamiento de los niños del coro, aquí todo es "turbación del culto divino y deshonestidades y menospreçio de la dicha santa yglesia ques casa de dios y de oracion", especialmente porque "los clerizones hazian muchas trauseras y desverguenzas ansi en el oficio de dia como de noche en los maytines" (ibídem 163). Para colmo, como ocurría en muchas otras iglesias, los excesos no eran protagonizados solo "por los benefiçiados [...] que eran nombrados por ofiçiales del dicho obispillo", sino también "por sus familiares y seruidores y otras personas que venían en avitos indecentes a cuya causa avía mucha perturbación y desasosiego en el oficio divino y los tales días" (ibídem 163). La algarabía de tal "costumbre y çerimonia del obispillo" no encajaba así en los fines doctrinales que el cardenal Tavera reconocía en una celebración que se había hecho en la Iglesia "de tiempo inmemorial aca y en todas las otras de estos rreynos para exemplo de umilldad y de la ynocencia que debe aver en los prelados y otras personas eclesiasticas y seglares" (ibídem 163). Pero habida cuenta de que "no hera justo por los excesos de algunos particulares quitar del todo la dicha costumbre y çerimonia tan antigua" (ibídem 163), el cardenal junto con el deán y el cabildo catedralicio ordenan que "la election y oficio del dicho obispillo se haga y celebre agora y de aqui adelante con la onestidad y moderaçion siguiente" (ibídem 163), preceptuando una serie de reglas tendentes a evitar el descontrol. Elegido "por votos de clavstro y clerizones en lescuela" (ibídem 164), el obispillo era investido el día de San Nicolás en un ritual en el que no se olvidaban los efectos especiales: situados los benefiçiados a un lado ("tras la puerta del perdon") y los clerizones en otro ("en vn tabernáculo cabo la capilla de nra. s. ${ }^{a}$ del estrella"), un ángel bajaría de una nube con el bonete del obispillo. Pero las prácticas de inversión del orden que más algarabía suscitaban, tenían que acabar: el cardenal prohíbe expresamente que entre los clerizones haya "sermon ni correo ni danças ni que echen monedas ni haya deshonestidad alguna" (ibídem 164). Por el contrario, ataviado el clerizón con el distintivo obispal, los beneficiados debían ir al coro "con toda quietud", mientras que el obispillo habría de sentarse "en un silla alta de dignidades con dos asistentes clerizones" (ibídem 164). El obispillo asistía hasta el día de los Inocentes con su capa y ganaba el sueldo de un racionero también hasta el 28 de diciembre, fecha en la que al parecer volvían a repetirse ciertas costumbres desordenadas que el cardenal se empeñaba en maniatar. Este asume que el obispillo se siente en el día de los Inocentes en la mismísima silla episcopal, y además que lo haga acompañado de sus asistentes, pero alerta de que no tolerará que realice el oficio divino, ni eche la bendición, "ni haga çerimonia alguna de prelado" (ibídem 164), prohibiendo expresamente que durante el día de los Inocentes el obispillo "gouierne en el coro". Vale que en la procesión el obispillo la presida con 
sus asistentes y que dignidades, canónigos y racioneros con sus capas se humillen siguiéndole, pero a juicio del cardenal era un claro exceso que el falso obispo, montado en caballo o mula, saliera a la calle acompañado de otros clerizones. Esto último, que era costumbre en el lugar, no se toleraría a partir de ahora. El cardenal recuerda que cualquier "desorden ó deshonestidad" de los beneficiados en cualquiera de los días entre San Nicolás y los Inocentes sería condenado con una pena de dos meses de sueldo y la prohibición de entrar en la iglesia durante los dos meses siguientes a la infracción, es decir, en enero y febrero. Entre dichas infracciones se citan expresamente los disfraces, prohibiéndose que cualquier beneficiado "se vistiere fuera del avito acostumbrado" (ibídem 164).

Estas dos muestras son suficientes para comprender la situación paradójica a la que se enfrentaban muchas fiestas burlescas del ciclo navideño, entre una pastoral que acogía la escenificación de la humildad a través del sometimiento del obispo y los escalafones superiores de la diócesis a los niños del coro, y, por otro lado, la necesaria contención a la que se obligaba la Iglesia para que aquellas inversiones de roles no se desmadraran. En muchos obispados se vivió este tira y afloja durante siglos. El primer sínodo diocesano celebrado en Jaén en 1368 ya consideró de obligada responsabilidad censurar estas celebraciones, e instaba a "que no se traíga aí almuerzo ni prediquen cosas deshonestas ni echen ajiles sucios ni enciensen con cosas de mal olor ni echen perros ni otras semejantes cosas" (Amezcua, 1997: 267). Casi dos siglos más tarde, y en la otra punta de la Península, en Gerona, el arcediano de Besalú proponía al cabildo la abolición del obispillo y el vicario general establecía el 24 de diciembre de 1541 que habría que "corregir les insolencias y desordens de cascun anni en les festes de Nadal se segueixen á respecte y per causa del Bisbato" (Milá y Fontanals, 1895: 214). Pero aunque las prohibiciones y quejas fueron constantes, no faltaron, como hemos visto, las visiones más permisivas, que justificaban la fiesta teológicamente, aunque censuraran sus mayores descomposturas.

Entre la permisividad hacia la fiesta del obispillo de fray Hernando de Talavera, primer arzobispo de Granada, y las censuras sobre los excesos navideños de fray Luis de Granada, media un abismo. Fray Hernando de Talavera muere en 1507. Fray Luis de Granada (1504$1588)$ tenía tres años. Lo que les separa no son solo esos ochenta años, sino el Concilio de Trento (1545-1563), que se afanó por reformar al clero y acabar con las diversiones indecorosas, que en el fondo consideraba parcialmente herederas del paganismo, como denunciaban los calvinistas. Trento dio al traste efectivamente con muchas de estas fiestas, pero otras pervivieron, porque el concilio no acabó con las justificaciones teológicas que las sustentaban. 


\section{LA NAVIDAD EN EL CONVENTO: DIVERSIONES POSTRIDENTINAS}

En 1663, la Inquisición actúa contra las monjas de la Capilla Real de las Descalzas, acusadas de escándalos y comportamientos licenciosos en la Navidad, como cantar coplas irreverentes:

Es público y notorio que en muchas iglesias de estos reinos, y con especialidad en conventos de religiosas, no sólo en las festividades de la Natividad del Señor y de los Santos Reyes, que son las que más obligan a singulares demostraciones de regocijo, sino en otras muchas festividades del año y estando patente el Santísimo Sacramento del altar, se cantan diversas letras de romance vulgar que se han cantado en teatros de la farsa, trovados a lo divino, pero con los mismos que llaman estribillos, sin diferenciar cosa alguna ni en letra ni en el tono (Paz y Melia, 1964: $\mathrm{X})$.

La propia Inquisición reconoce que son los días entre Navidad y Reyes los que obligan a "singulares demostraciones de regocijo", pero se ve obligado a actuar ante lo que considera excesos. El chivatazo lo había dado un religioso de la Orden de San Francisco de Paula, un tal fray José Méndez de San Juan, de 56 años, quien se presentó voluntariamente ante el Santo Oficio. Denunciaba que en fechas señaladas —el Sábado Santo o la Navidad- las monjas de la Capilla del Convento Real de las Descalzas cantaran villancicos profanos e indecentes, después de entonar los cánticos píos. Lo que molestaba al religioso es que en ciertas fechas (en la Pascua de Navidad y en la de Resurrección) se difuminaran los límites entre la plaza, la calle, la iglesia y el convento, con "mezcla de cosas profanas con las sagradas":

Por la Navidad la dicha Capilla cantó un villancico trovando a lo divino el Mundo nuevo, que pregonan por las calles unos franceses o alemanes, y entre otras coplas, hay una del milagro que Cristo, Señor nuestro, hizo en las Bodas de Caná de Galilea, y diciendo que había convertido el agua en vino, inmediatamente contrapone los taberneros de Madrid, que hacen lo contrario (Paz y Melia, 1964: X).

Así, pues, siglos después de las misas paródicas medievales y de los cantos goliárdicos que acentuaban con equívocos religiosos el triunfo de la taberna (Bayless, 1996), las monjas seguían cantando villancicos ambivalentes. Las prohibiciones de los concilios y sínodos, repetidas siglo tras siglo, no lograron acabar definitivamente con los villancicos burlescos. Por ejemplo, y como otros sínodos, el celebrado en Badajoz en 1501 repudiaba las representaciones deshonestas y risibles, así como los "cantares torpes e feos", que se podían oír en las iglesias y 
monasterios de la diócesis con motivo de la Navidad y la Resurrección. El sínodo advierte que la alegría, por dichos misterios, "ha de ser toda espiritual", y que "si algunas cosas quisieren cantar en tanto que las leciones se dizen, que sean cantares devotos" (sínod. de 1501,11, en García y García, 1990: 76-77). Pero ni siquiera el espíritu de Trento logró erradicar por completo estas controvertidas expresiones de júbilo, y así, al menos hasta el siglo XIX, fue costumbre de conventos, catedrales e iglesias encargar villancicos más o menos divertidos, para las fiestas navideñas. En ocasiones, incluso se editaban. Uno de ellos (BravoVillasante, 1978: 73-75), cantado en el Real Convento de la Encarnación en la noche de Reyes de 1676, deja a las claras el gusto por la mezcla jocoseria (incluyendo el uso del latín macarrónico), la apuesta por la celebración gozosa, la alegría y la risa. El villancico en cuestión exalta lo ínfimo y lo bajo (arquetípicamente representado en el bobo y el loco), y paralelamente ridiculiza al que ostenta poder y estatus (el linajudo y el predicador), todo ello acorde por un lado con la celebración del nacimiento del Dios de los humildes y pobres, y por otro con la representación del mundo al revés, tópico que se prestaba tanto a los regocijos carnavalescos profanos como a estas diversiones clericales. Hoy puede sorprendernos que en un convento se exaltara a bobos y locos, mientras se escenificaba un diálogo burlesco entre un gracioso predicador y un ridículo linajudo, pero durante siglos, y a pesar de la incomprensión y persecución por parte de un sector de la Iglesia, este tipo de manifestaciones risibles navideñas encontraban acomodo especialmente entre las órdenes y los religiosos más apegados a la sensibilidad popular.

De la Nochebuena, dizen

sus católicos devotos, que no son cuerdos, los que no se alegran como locos.

Con este intento a la fiesta vienen los dos más notorios; que es el uno Linajudo, y predicador el otro.

Oyganlos, y nadie de ellos diga mal, porque a sí propio se agraviará, el que hable mal del que es pariente de todos.

Aora salga el Rector, que entre locos, no es impropio, que el que ha de ser el postrero salga el primero de todos. 


\section{Estrivillo}

Atención a los locos, que esta noche son ellos los más devotos; pues si nace de amor la alegría, más amor tiene quien tiene más gozo.

Coplas

Predicador: Hermanos; oy nace Dios In saecula saeculorum, Pax vobis.

Que esta noche han de tener paz los bobos.

Linajudo: $\quad$ Los bobos eran de Coria. Y son mis parientes propios; hijos por parte de Abuelo del Mariscal, y del otro que casó en Nabal Carnero, sobrino de los Redondos; que son primos por tres partes, y los quemaron a todos.

Todos: $\quad$ Victor, victor los locos.

Predicador: $\quad$ Nace Dios en un Pesebre; Nascit in paxis paxorum; Los pajes andan a pie, Dios nace del mesmo modo [...]

(Bravo-Villasante, 1978: 73-74).

Estos diálogos bufos, semejantes a los que protagonizan los pastores bobos de los autos navideños de Juan del Encina, Lucas Fernández, Gil Vicente, Diego Sánchez de Badajoz y otros dramaturgos del Renacimiento, pervivieron en los villancicos y las representaciones parateatrales cómicas conventuales. De hecho, sabemos que en el siglo 
XVII los conventos competían en fama por sus dotes para representar dramas y cantar villancicos, atrayendo al mayor número de feligreses. Qué tipo de juegos escénicos representaban monjes y monjas durante la Navidad, lo sabemos entre otros por los estupefactos comentarios que dejaron algunos viajeros extranjeros, tras asistir a las alocadas celebraciones de los frailes, dignas de las mejores mascaradas carnavalescas. En 1659, justo un siglo después de la prohibición de danzar en las iglesias dictada por Felipe II, el diplomático francés François Bertaut dejó anotado en su diario las diversiones de los franciscanos en la misa de Navidad:

Hacía una niebla horrible y muy fría cuando llegué a Valladolid el miércoles, víspera de Navidad [...]. Fui a la misa de medianoche en los franciscanos, donde me consolé de la pérdida que había hecho de no estar en Madrid para ver las comedias que los frailes representan en su convento, en el coro de su iglesia, esa noche, para regocijarse del Nacimiento de Nuestro Señor.

Me costaba trabajo creer lo que un librero, en cuya casa compré libros, me dijo, que había escrito la comedia el mariscal de Biron, en versos burlescos a un fraile que la debía representar en su convento, y que su mujer había prestado su vestido a uno de ellos para eso. En efecto, vi alguna cosa que valía bien la pena; porque en cuanto abrieron las puertas de la iglesia, donde esperaba una multitud de pueblo, vi los tamboriles vascos que se ponían acordes con los órganos que tocaban una chacona.

Fue aquello la preparación de los maitines, después de los cuales vi a un fraile que llevaba un sobrepelliz, y que después de haber hecho lo que tenía que hacer en el altar, se quitó ese sobrepelliz y se fue a la sacristía para mostrar una casaca de traje de máscaras que llevaba debajo.

Poco después abrieron la puerta de abajo de la iglesia, por donde, siguiendo a la cruz y los candeleros de la procesión, entraron multitud de frailes con disfraces tan ridículos como los de los días de carnaval de París, grandes narices, barbas postizas, trajes grotescos, bailando y saltando con tamboriles vascos y violines que se acordaban con los órganos.

Había entre ellos algunos que llevaban dos imágenes bien vestidas, la una de la Virgen y la otra de san José, a las que hacían bailar; después venía otro que llevaba una cuna donde estaba el Niño Jesús, y después de haber hecho locuras, colocaron al Niño sobre los escalones del altar, donde todos los franciscanos, unos tras otros, le fueron a adorar; luego las máscaras se fueron. 
Pusieron al Niño con San José sobre el altar, y comenzaron la misa. Creía fuese aquello todo, pero antes del prefacio vi desde lo alto de la tribuna del coro, que está en alto en todas las iglesias de los frailes de España, un franciscano con su traje de máscara y un antifaz a lo Gautier Gauguille, que se puso a cantar con una guitarra un villancico de una mula que coceaba. El pueblo gritaba '¡Víctor!' a cada momento y tan alto que yo casi no podía oír nada. Con trabajo lo pudieron hacer callar con la campanilla, mientras el sacerdote decía el Per omnia (García Mercadal, 1999, III: 459460).

De esta manera hacían realidad estos franciscanos el mandato de su fundador para convertirse todos en joculatores domini (juglares del Señor), algo que debían cultivar especialmente en Navidad, como hacía, por ejemplo, San Francisco Solano, el misionero nacido en Montilla en 1549, cuyos hagiógrafos alaban que el santo saliera en Navidad cantando chanzonetas con su rabelino "dando vueltas y saltos de contento" (Plandolit, 1962: 236). Los numerosos testimonios de los siglos $\mathrm{XVI}$ al XVIII demuestran que estas representaciones burlescas navideñas no eran simple práctica anecdótica de ciertos cenobios, sino una costumbre generalizada y en modo alguno exclusiva de franciscanos. El predicador y teólogo francés Juan Muret mostraba así su repudio ante uno de estos festejos, celebrado en 1666, aunque reconocía verse arrastrado por el torbellino burlesco:

Sabéis cuánta veneración tiene la noche de Navidad entre nosotros, porque si se exceptúa alguna juventud que se espera para comer tocino al venir de la iglesia, todos los otros la celebran con piedad y no tratan sino de preparar bien su conciencia para aproximarse dignamente a la santa mesa. Aquí, al contrario, es la noche más escandalosa de todo el año; no sirve más que para citas, una embriaguez casi general y comedias, para las que escogen el altar para teatro, y de las que los mismos religiosos son los actores. En cuanto a mí, que jamás había querido creer las irreverencias tan monstruosas, aunque me hubiesen hecho de ellas un relato muy seriamente, no dejé de ir a verlo para convencerme por completo; y como me habían dicho que los capuchinos hacían también peor que los otros, fui a los de la Paciencia, ${ }^{12}$ que están en grande reputación. Encontré al llegar una multitud de franceses delante de la puerta que reían por anticipado haciéndose recordar los unos a los otros las bufonadas que en los años precedentes habían visto. Después, habiéndose abierto la puerta, entraron en la iglesia como en lugar profano,

${ }^{12}$ Se trata de un convento, fundado por Felipe IV en 1639 y demolido en 1837. 
corriendo y apresurándose para tomar el mejor sitio, y la mayor parte sin quitarse el sombrero ni ponerse de rodillas. Después de un ruido espantable de no sé cuántas voces diferentes con que unos se decían en voz alta todo lo que tenían para cenar, otros los brindis que habían hecho, a la moda de Alemania; algunos, las muchachas que habían requebrado, y todos miles de cosas que eran indignas del lugar en que estaban, se hizo de pronto un gran silencio porque descubrieron venir un fraile con un pequeño barril, o sea un tambor, que golpeaba lo más que podía, y otro con un pífano, que se dejaba oír desde hacía un medio cuarto de hora, y que al principio habíamos creído fuese en alguna casa próxima; había tocado mientras sus compañeros se vestían, después de lo cual se unió al tambor para acompañarlos a su compás. Aquí fue, señor, donde no pude ya contener la risa. Me olvidé de la santidad del lugar en donde estaba, y con mucho más transporte que si hubiese visto a Scaramouche en el teatro con su compañía, me abandoné a inmoderadas carcajadas. En verdad que me hubierais perdonado en esa ocasión, porque no sé quién es el hombre tan serio que no hubiese hecho otro tanto como lo que yo hacía (García Mercadal, 1999, III: 554-555).

Muret narraba en su carta a un consejero del Parlamento de París los pormenores de dicha celebración. Después de un anárquico introito musical, en que algunos frailes tocaban el tambor o el pífano mientras los demás se iban poniendo los trajes para la representación, daba comienzo la función:

Apareció una partida de religiosos disfrazados con largas barbas representando los pastores de Belén, con trajes mitad a la española, mitad a la francesa, a la alemana, en una palabra, un poco de cada nación. Mal vestidos, os dejo que os los imaginéis, enharinados de suerte que no se les podía reconocer: algunos se habían embadurnado el rostro con carbón y llevaban, los unos un cordero al hombro, los otros un pellejo de vino, los otros un cesto lleno de gallinas, los otros de huevos, los otros de quesos, y marchaban riendo y saltando. Ese grupo de barbudos iba seguido por otro de legos, que iban vestidos de pastoras, con parecidos presentes, y hacían la corte a la Santísima Virgen, que estaba en el extremo con san José. La hicieron sentar en el suelo, cerca de un montón de paja, donde puso al Niño Jesús, y le miraban con mucha alegría, mientras los pastores hacían mil gestos. Es imposible el pintároslo. Os diré solamente que jamás he visto nada tan inmodesto. [...] Tan pronto como se hubieron desembadurnado, volvieron a entrar en la iglesia de dos en dos, con cirios, yendo la cruz delante, y el guardián, que venía detrás llevando el Niño Jesús entre sus dos brazos, se fue a sentar sobre la escalinata al 
pie del altar, donde le habían preparado una silla. Allí, después de un cántico de la iglesia, cantado a su modo, le fueron a besar los pies por orden de antigüedad, y se volvieron cantando del mismo modo (ibídem 555).

Como de costumbre, el sacerdote galo -que asiste a la representación del auto navideño- hubiera preferido otro tipo de celebración más piadosa, y no esta algarabía heredera, según él, de las irreverencias del paganismo:

Se excusan por lo regocijante del día, pero me parece que podrían contentarse con esa alegría interior que no viene más que de Dios solo y que nada tiene que ver con las solemnidades bufas del paganismo; o bien, si quieren mostrar su alegría por alguna señal exterior, me parece que sería bastante con una procesión que hicieron un cuarto de hora después y que fue verdaderamente tan edificante como el resto había sido escandaloso (ibídem 555).

Podrá pensarse que la chocante costumbre monacal habrá desaparecido en la actualidad, y en la mayoría de los casos así es. Sin embargo, muchas de estas costumbres pervivieron en la Edad Moderna. Por pleitos y denuncias nos han llegado episodios más o menos irreverentes protagonizados por clérigos, como ciertas inocentadas y bromas que gastaron, al parecer, en 1813 un fraile (el padre Marcos Torrubia), un cura de Motizón (Jaén) y otro sacerdote (Felipe Majón), que ejercía de hermano de las Ánimas en Villanueva del Arzobispo. Como en muchos otros pueblos, también en esta localidad pervivió la costumbre el 28 de diciembre de salir a la calle para hacer recuesta para las ánimas benditas, siendo diversión supeditar la limosna a que otros realizaran las acciones más extravagantes y risibles. Parece que a los tres religiosos se les fue la mano en cierta ocasión, lo que originó una denuncia de algún alma piadosa y una información pública en el Arzobispado:

Los hermanos que piden limosna para misas y sufragios a las benditas ánimas están muy irritados contra el padre don Marcos Torrubia porque tuvo el atrevimiento y desvergüenza de ofrecer cuatro reales de limosna si hacían que el señor cura don Juan de Mata se orinase en las ánimas que llevaban en la taza de las limosnas (Amezcua, 1997: 270).

La broma, en la que habrían participado los tres religiosos ante las carcajadas de la concurrencia, respondía a otra inocentada que algunos vecinos le habían gastado al padre Torrubia, ofreciendo una limosna de 15 reales porque la hermana de este bebiera de la fuente en la plaza, lo que tuvo que impedir el joven fraile soltando de su bolsillo 16 reales "para las ánimas benditas". El altercado podría considerarse un episodio de 
locura transitoria o irreligiosidad, si no se enmarcase dentro de las licencias permitidas en el día de los Inocentes, en las que ciertos religiosos participaban cuando en Villanueva el Ayuntamiento entregaba el bastón de la autoridad a los hermanos de las Ánimas, para que estos en la noche de queda pudieran multar a su antojo a los vecinos. El ejemplo no es aislado. A pesar de las reiteradas censuras hacia la fiesta del obispillo, Milá y Fontanals (1895: 215) cuenta cómo esta se seguía celebrando en su época en el monasterio de Montserrat, donde se elegía un abad entre los niños del coro, otorgándole cierta jurisdicción. $Y$ en el siglo XX, muchos seminarios y conventos mantuvieron la celebración de su Rex innocentorum, que sustituía efímeramente al abad, permitiéndose no pocas bromas que rompían con la habitual monotonía claustral. Uno de nuestros informantes - hijo de Valladolid, pero afincado en Sevillaaccedió a narrarnos, por escrito, su experiencia en la primera mitad de los años 60 del pasado siglo. El Colegio Mayor de Salamanca, bajo la advocación de San Alberto Magno, era regido por la Congregación de los Hermanos de La Salle, y allí cursaba él los estudios de Filosofía y Teología como Facultad adscrita a la Universidad Pontificia de Salamanca. El relato sobre la fiesta de los Inocentes en el Colegio Mayor, tal y como lo recuerda este antiguo fraile (hoy catedrático de literatura jubilado), demuestra que las diversiones burlescas estaban al orden del día:

El día 27 de diciembre se procedía con toda solemnidad a la elección del que sería coronado y entronizado como Rex Innocentorum al día siguiente. Ya durante los días anteriores se grababan diversos programas en cinta magnetofónica, como si fueran radiados, para calentar el ambiente electoral. Se barajaban "en las ondas" varios candidatos cualificados, cuya candidatura era impuesta más como una humillación que como un honor, aunque nadie podía resistirse ante el veredicto de las urnas. El candidato oficioso de los protagonistas radiofónicos respondía - haciendo omisión de los apellidos-al antropónimo de Francisco Agustín. La audiencia estaba entregada al casi seguro ganador que se mostraba un tanto remiso. Durante dos días el bombardeo de cuñas radiofónicas fue incesante. Mientras se hablaba de los méritos de los posibles pretendientes, y la emisión hacía gala de imparcialidad bajo el lema incesantemente repetido de: "Radio Bote es imparcial; Radio Bote no vota a nadie", otros dos presentadores repetían en voz baja pero audible, durante largos minutos: "Vota a Francisco Agustín; Vota a Francisco Agustín".

Estalló entonces una rebelión interna. Cansados de la manipulación, los miembros de un grupo nos propusimos presentar a otro candidato: precisamente al autor de la manipulación y director del programa "radiofónico". Se llamaba Manuel José. 
Mientras aún seguía la propaganda, comenzamos, primero a susurrar, luego a cantar y a gritar y vociferar finalmente el nombre del gracioso. Más de los dos tercios se sumaron al clamor que exigía, con un ritmo infernal, la presentación de la nueva candidatura. Pero los adeptos de la primera clamaban por el que hasta hace poco parecía el aspirante más cualificado, mientras un pequeño grupo pero muy consistente gritaba una tercera candidatura. Nicolás era su nombre. Durante más de una hora y a voz en cuello, los tres grupos se desgañitaban para que su candidatura resultase más sonora. El ritmo de los tres supuestos "inocentes" era diferente y daba lugar a un curioso contrapunto entre Francisco Agustín, Manuel José, Nicolás, heptasílabo, pentasílabo y tetrasílabo respectivamente.

Finalmente, tras defender con argumentos de peso las diferentes candidaturas, tuvo lugar la reñida y secreta elección. Nicolás fue eliminado en la primera ronda, con el desencanto de su grupo de seguidores, minoritarios pero vociferadores como pocos. En el "ballotage" subsiguiente, obtuvo mayoría de votos el director de la cadena radiofónica, el alguacil alguacilado, Manuel José. Lo tomó con deportividad y se cerró la sesión. Al día siguiente tendría lugar la coronación oficial.

El día 28 se vivieron los acontecimientos con cierto nerviosismo, no exento de zumba. Tras una comida especial y abundante, seguida de café y copa, ingredientes no muy corrientes en la ascesis casi conventual del Colegio Mayor, se procedió con todos los honores a la coronación del elegido por votación popular. Un poco tenso, pero sonriente y aceptando con deportividad los designios democráticos, Manuel José subió por unos escalones al trono que se le había dispuesto. Fue coronado en una ceremonia solemne y se le ofreció el cetro con el que debía gobernar con mano clemente su pequeño y temporal imperio. El manto de púrpura con el broche correspondiente le daba una prestancia singular, mientras un escabel a sus pies le ofrecía comodidad y distinción. Los dos candidatos frustrados, vestidos para la ocasión como alguaciles o pajes, se colocaron a ambos lados.

Durante toda la tarde se siguió un programa largamente elaborado de canciones, chistes, chascarrillos, ocurrencias, historias y concursos, largamente aplaudidos y premiados bajo el cetro del "obispillo". Una de las ocurrencias más regocijantes consistía en el recitado de poesías diversas en latín macarrónico, fácilmente inteligibles aun para los menos versados en la lengua ciceroniana. Aunque lo he intentado, no me ha sido posible reproducir completa ninguna de las que se dedicaban a profesores 
y compañeros, todas ellas de carácter satírico-festivo. A modo de ejemplo, pongo algunas estrofas que recuerdo de otra ceremonia solemne, propia del equinoccio de primavera, en la época de la Pascua Florida. Decía más o menos así: "Finit iam trimestrem secundum / et sumus iam in tercerum / in quem examines proximos / pavor infundent, et miedus. / Ante mamotretus multus / "debetis multo estudiare" / eos dicent professores / ut ad ire examinare / pasetis paucos sudores. / Sed, cachis diez, hombre...". No logro recordar la continuación.

La historia se repitió otros dos años. Pero jay! al severo y ascético hermano rector del cenobio colegial le pareció que se quebraban las reglas eclesiásticas propias de la época y se cambiaba el júbilo por el Nacimiento del Niño por otra alegría de carácter paganizante. Era demasiado estrepitoso el alborozo para que fuera legítimo y pudiera cursar paralelo, sin remordimiento, con la verdadera "alegría conciliar ecuménica" de la que el Concilio Vaticano II se había hecho eco por aquellas fechas. El hermano rector, investido de autoridad absoluta, ordenó suspender las fiestas de la elección del Rex Innocentorum y hubo que acatar con tristeza la orden revocatoria. Nunca más volvió a celebrarse, pero su grato recuerdo acompañará siempre a los participantes de aquella especie de orgía desenfrenada.

Efectivamente, muchas de estas diversiones fueron prohibiéndose aquí y allá. Sin embargo, aún hemos podido comprobar en pleno siglo $\mathrm{XXI}$ alguna muestra de regocijo clerical, que mantiene viva esta singular vis comica en el tiempo navideño. Los monjes del monasterio cisterciense de Santa María de Huerta (Soria), por citar un solo ejemplo, no solo se gastan bromas el día de los Inocentes (como enviar entre ellos falsas cartas de alguna presunta enamorada o transmitir supuestas órdenes del abad para realizar los actos más humillantes), sino que disfrutan los días entre Navidad y la Epifanía de ciertas relajaciones, impensables en otra época del año: beben una ración extra de vino y les es permitido hablar durante las comidas, celebran por la tarde-noche guateques, y representan obras de teatro burlescas ante las monjas del Sagrado Corazón que, como ellos, acudieron en 1930 a repoblar monásticamente el lugar, después de la desamortización de 1835. Allí, según un breve trabajo de campo realizado en el año 2007, la justificación que daban los monjes se centraba más bien en las singulares manifestaciones de alegría navideña que habrían de permitirse so pretexto del nacimiento del Señor dentro de la teoría de la eutrapelia que ve con buenos ojos la ritual relajación de la severidad conventual en los momentos más jubilosos del ciclo anual. 


\section{LA EUTRAPELIA}

En el año 1400 el rector de la Universidad de París condenaba la polémica fiesta del asno (festum asinorum), pero el claustro de la Facultad de Teología acababa justificando la pervivencia de una festividad que levantaba no pocos resquemores en los obispos y papas más severos:

Nuestros eminentes ancestros han permitido esta fiesta. ¿Por qué se nos ha de prohibir ahora? Los toneles de vino estallan si no les sacamos los tapones de vez en cuando para orearlos. Así también nosotros, viejos barriles que el vino de la sabiduría nos haría estallar si lo conservásemos exclusivamente para el servicio de Dios. De esta manera, durante diversos días del año, lo ventilamos, nos abandonamos - para divertirnos según la tradición- a los placeres más exuberantes y a la locura, que es nuestra segunda naturaleza y parece ser innata en nosotros, y así, después volvemos con mayor entusiasmo a nuestros estudios y al ejercicio de la santa religión (Massip, 1992: 26-27).

El reconocimiento de la debilidad humana y de su naturaleza pecadora parecía especialmente razonable en la celebración de la llegada de un Cristo hecho hombre, como nosotros. Así como el Carnaval preludia la abstinencia cuaresmal, las fiestas de locos permitían anticipar la ordinaria contención religiosa, a la vez que servían de válvula de escape al rigor y el monótono tedio. El argumento es tomista. Frente a Padres de la Iglesia como San Juan Crisóstomo, para quien la diversión y el placer eran frutos del diablo, nunca de Dios, otros como San Agustín defendían el valor liberador del juego y la alegría, y veían razonable que el sabio relajara en ocasiones el rigor en su disciplina. Es la antigua teoría de la eutrapelia, que abraza Santo Tomás. En la Suma Teológica argumenta que al igual que el cansancio del cuerpo requiere del descanso del cuerpo, el cansancio del alma se restaura mediante el descanso del alma, es decir, mediante "algún deleite, procurando un relajamiento de la tensión del espíritu".

Así leemos, en las Colaciones de los Padres, que el evangelista San Juan, cuando algunos se escandalizaron al encontrarlo jugando con sus discípulos, mandó a uno de ellos, que tenía un arco, que tensara una flecha. Después de haberlo hecho muchas veces, le preguntó si podía hacerlo ininterrumpidamente, a lo que el otro respondió que, si lo hiciera así, se rompería el arco. San Juan hizo notar, entonces, que se rompería también el alma humana si se mantuviera siempre en la misma tensión. Estos dichos o hechos, en los que no se busca sino el deleite del alma, se llaman diversiones o juegos. Por eso es necesario hacer uso de 
ellos de cuando en cuando para dar algo de descanso al alma ( $S$. Theol. II-II, q. 168, a. 2).

Se trata de la misma argumentación que utilizan los teólogos para salvaguardar las fiestas de locos, como hemos visto en el testimonio de la Facultad de Teología de París. El juego es necesario, especialmente para el hombre contemplativo, que necesita restaurar las fuerzas del alma. El fastidium asedia al religioso, el tedio es enemigo del aprendizaje y la vocación. El juego, la diversión, permitían el descanso y suponían además un recurso didáctico. Naturalmente, Santo Tomás establecía límites precisos: las diversiones debían ser honestas, adecuadas a las circunstancias y el contexto, alejadas en todo caso de las palabras torpes y nocivas. Pero como escribía también en el Comentario a la Ética de Aristóteles, el pecado está en el exceso, no en el ludus en sí, que es útil al hombre, pues le aleja de los pesares vitales (Ethic. 4, 16, 2). Tomadas stricto sensu, ciertas locuras festivas navideñas iban más lejos de lo que propugnaba cualquier teoría de la eutrapelia, aunque lo arraigado de esta permitió a muchos teólogos, canónigos y miembros del bajo clero ensanchar la permisividad, pese a que se violentaran e interpretaran libremente las palabras de San Agustín, San Pablo y Santo Tomás. La Iglesia no solo hizo la vista gorda para no espantar al pueblo o para intentar introducir sus verdades bajo el ropaje del juego y la diversión, sino que con cierta concepción de la eutrapelia abría las puertas a las prácticas lúdicas y risibles, máxime cuando aquellas relajaciones venían además a escenificar uno de los valores fundamentales del cristianismo: la humildad.

La alegría festiva por el misterio, la teoría de la eutrapelia y la concepción de la humillación como camino para la humildad han sido las principales justificaciones eclesiásticas para este tipo de fiestas. Otros argumentos han pugnado históricamente contra la corriente hegemónica (pero no exclusiva) que consideraba estos actos censurables, aunque en muchos casos dichas justificaciones remitían reiteradamente al leitmotiv de la humildad y la pobreza. Así, por ejemplo, la posibilidad de satirizar las locuras del mundo, entre otras las del propio clero, ha sido durante siglos una de las razones que aconsejaban la pervivencia de esas locuras festivas, en contra de los que - como San Bernardo- abogaban por una didáctica de la penitencia. Durante la Edad Media y el Renacimiento, el tópico de la locura sirvió para las sátiras contra los altos dignatarios de la Iglesia. Solo en un contexto de popularidad de los códigos carnavalescos, aptos para su utilización crítica, pueden comprenderse episodios como el protagonizado por un monje, maestro de la Universidad de París, quien durante un sermón en un sínodo al que asistían el rey y muchos obispos, inició su prédica — después de citar a San Pedro y San Pablo- con el grito con que el pueblo saludaba a los locos: “ibabimbaboo!”. El monje razonaba siguiendo las enseñanzas de 
San Pedro y San Pablo, que para aquel entonces constituía casi un tópico literario: "Los obispos con sus enjaezados corceles y sus delicadas vajillas, con sus costosos trajes, sus vicios y sus deleites, creen que irán al cielo. Así, Pedro y Pablo, que sufrieron pobreza y tribulación, hambre y sed, fueron los más grandes locos" (Owst, 1966: 242).

Es, en el fondo, el mismo argumento que desarrolla Erasmo en Elogio de la Locura. Cristo prefiere a los "espíritus sencillos y rústicos" (Erasmo, 2002: 177) y "detesta a los sabios que se ufanan de su prudencia" (ibídem 177); desprecia a los fariseos, a los escribas y a los doctores, y por el contrario "se le ve deleitarse con los niños, mujeres y pescadores" (ibídem 178). Cristo está con los tontos, dice Erasmo. Siguiendo una larguísima tradición exegética que se remonta a los primeros Padres de la Iglesia (San Gregorio Magno, por ejemplo), Erasmo interpreta como acción simbólica el hecho de que Cristo en la entrada triunfante en Jerusalén "quiso cabalgar en asno, cuando, si hubiera querido, habría podido hacerlo sin peligro en el lomo de un león" (ibídem 178). Ahí está la justificación de una práctica burlesca, utilizada para escarnecer y humillar al reo, pero también para advertir al misacantano de su necesaria humildad o jugar ambivalentemente con el simbolismo cristológico en la festum asinorum, en la que el asno constituía una alegoría del propio Jesús (Arlt, 1970: 57).

Así, pues, la vergüenza sancionadora y la risa regeneradora se revolcaban juntas en manifestaciones ritual-festivas con la suficiente ambigüedad como para permitir la coexistencia de diferentes sentidos. Solo bajo una teología de la humildad, unida al contexto de alegría por el nacimiento de Cristo, cierta concepción de la bondad en las relajaciones rituales y la eficacia simbólica y festiva de la inversión de roles, pueden explicarse hechos sorprendentes como los banquetes con que cada 28 de diciembre se hacía disfrutar a los locos internados en el hospital de Inocentes sevillano, que tal día eran servidos y agasajados; ${ }^{13}$ la

${ }^{13} \mathrm{Al}$ menos desde el siglo XVII, dos fechas rompían en el hospital de los Inocentes de Sevilla una vida animal de hambre, frío y abandono: el día de los Inocentes y el de los patronos del hospital, santos Cosme y Damián. Sin duda, el 28 de diciembre era el día más esperado por los locos internados en el hospital, que podían olvidar por unas horas la monotonía de misa y rosario cotidiano, impuesta por el administrador y el capellán. La celebración daba comienzo en las Vísperas del día anterior y continuaba con una misa solemne el día de los Inocentes. Los sacerdotes lucían sus mejores galas, el altar mostraba por un día un inusitado esplendor con flores, luces, joyas. El hospital contrataba a un organista que tocaba durante la misa o incluso a un grupo de músicos para todo el día. La precaria situación económica del hospital parecía olvidarse: había para pagar a los Beneficiados de San Marcos, incluso para contratar a algún predicador de enjundia, que recibía hasta 60 reales de vellón por cada uno de los dos sermones. Pero no solo clérigos celebraban la fiesta 
costumbre, incluso, de dejar sueltos por las calles a esos locos o liberar a algún preso el día de Navidad o el de los Inocentes; ${ }^{14}$ o el que la Iglesia alentara a que los ricos y poderosos se humillaran tales días sirviendo en los banquetes, o al menos, rascándose el bolsillo para honrar al más pobre de los niños, que era coronado así como rey de la faba (Baleztna, 1979), una versión más de los reinados rituales de Navidad que venían a coronar a un humilde, tal y como había aleccionado al hombre el rey de reyes.

\section{LA BURLA LIMINAL}

Alertábamos páginas atrás sobre la tendencia a vincular prácticas semejantes de diferentes épocas históricas, como si unas derivaran de otras más antiguas, siendo estas su origen y raíz. No hay que olvidar sin embargo que, más allá de las diferencias en la religión, los dioses, el sistema de creencias y en la teología, confluyen en las fiestas del ciclo navideño de diferentes épocas ciertas circunstancias comunes: la celebración del nacimiento de una deidad (sea Apolo, Sol, Helios o Cristo), el comienzo y el fin de un período (fin de año, año nuevo) y de una estación (marcada por el solsticio de invierno), así como ciertas variables asociadas al tiempo astronómico-meteorológico y su incidencia

con los locos del hospital. Por una sola vez en el año, los dementes tenían contacto más o menos abierto con el resto de ciudadanos, que venían a visitarlos, muy especialmente los notables de la ciudad. Antes de la celebración de la Navidad, los locos habían recibido vestimentas nuevas, al igual que a los hermanos ermitaños que salían con ellos por las calles a pedir también se les regalaba un hábito nuevo. Hermanos ermitaños, sacerdotes, músicos, ciudadanos y locos internados celebraban juntos un banquete inconcebible. Algunas de las dementes eran vestidas con mantillas y ayudaban a servir todo tipo de comida, para cuya elaboración se contrataba a dos cocineras. No faltaba la carne; según los años, puerco, carnero, conejos, pavos, asadurillas de cabrito. En otras ocasiones, se añade pescado: desde bacalao hasta besugo. Los postres no envidiaban en ingredientes y preparación a los de cualquier casa notable de la capital hispalense: costradas rellenas de peras, nueces, castañas, pasas de Almuñécar, almendras, platos de hojuelas y orejones, arroz con leche. A los huéspedes se les agasajaba además con dos platos de natillas, y para los porteros de la Audiencia que tal día asistían a la puerta del hospital, se preparaba chocolate. Los escritos de gastos de la época incluyen también el vino, que acaso no estuviera vedado tal día para los propios locos. Los locos debían soñar durante el resto del año con la abundancia, variedad y exquisitez de aquel banquete. El país de Jauja y el mundo al revés se hacían realidad por un día. Véase López Alonso (1988: 196201).

14 "Aún no os he hablado de una ceremonia que se hace el día de Navidad en las cárceles. El virrey se dirige allí seguido de una numerosa corte, y tiene el poder de libertar a los presos a los que quiere conceder la gracia", escribe un viajero francés en 1756 (García Mercadal, 1999, V: 28). 
en el ciclo agrario que en conjunto han influido poderosamente en diferentes culturas, y muy específicamente en la concepción mitopoética del tiempo (Caro Baroja, 1965: 18). Si los historiadores han descubierto similares maneras de aprovechamiento agropecuario o estructuras políticas en sociedades sin contacto entre sí, no menos ejemplos hay en el terreno de lo imaginario, mitológico y ritual, como supo ver con respecto al tiempo mitológico Henri Frankfort (1951). El tiempo puede ser experimentado y vivido como una sucesión dramática, cíclica, cambiante de etapas que son percibidas en términos polarizados de veranoinvierno, vida-muerte, alegría-tristeza, y en la cual los tránsitos entre una y otra merecen ritos específicos. Se trata de una temposensitividad cualitativa, concreta, cíclica y bipolar, que ciertas culturas agroganaderas han experimentado en diferentes lugares y épocas históricas.

La antropología social ha demostrado que ciertas circunstancias comunes que acontecen al hombre allá donde esté (como la muerte, por ejemplo), pueden generar dramatizaciones rituales diferentes pero que guardan, sin embargo, mito-lógicas comunes. Así los velatorios de difuntos, en que los asistentes bailan, cantan, beben y comen, con profusión de actos cómico-festivos para despedir al muerto, constituyen una práctica extendida a lo largo de la historia y la geografía mundial. Formaban parte de los rituales de los antiguos eslavos (Vyncke, 1992: 26) y era también práctica asumida por los cristianos, de lo que se queja Burcardo de Worms en el siglo $X .{ }^{15}$ La diversión, la risa, la música y el baile en los velatorios, especialmente en los de niños, fue uso en muchos lugares de España hasta bien entrado el siglo XX, como demostró la encuesta que hizo el Ateneo de Madrid sobre las costumbres de nacimiento, matrimonio y muerte. ${ }^{16} \mathrm{Y}$ aún en la actualidad, muchos pueblos de América conservan una costumbre, que a la mayoría de occidentales le repugna por macabra. Lo hemos conocido en los Andes

15 “¿Has hecho vigilias fúnebres, es decir, has participado en los velatorios de difuntos en que los cuerpos de los cristianos eran asistidos según el rito pagano, y has cantado nenias diabólicas y has bailado las danzas que inventaron los paganos, instruidos por Satanás; has bebido o te has abandonado a risas descomedidas y, dejando a un lado todo sentimiento de piedad y de compasión, parecía como si te alegraras por la muerte del hermano?" (Burcardo de Worms, Decretorum libri XX: PL 140, 960-976, apud Giordano, 1983: 186-187).

${ }^{16}$ Así, por ejemplo, en Alcaracejos el informante dice que "los velatorios de párvulos se consideran por el elemento joven como motivo de diversión, llegando el caso hasta de bailar en ellos, lo cual constituye un sarcasmo para los padres del niño muerto. El mucho personal forastero que no permite estos abusos, cuando por desgracia sufre la pérdida de algún hijo, va modificando esta costumbre que está llamada a desaparecer" (Limón, 1981: 300). En la Alpujarra pervivió esta costumbre, según nos han dicho algunos ancianos de la Contraviesa, hasta principios del siglo XX. 
ecuatorianos, donde ha sido uso tanto entre mestizos como entre grupos indígenas (los Saraguro, por ejemplo), y otros antropólogos lo han observado entre diferentes pueblos del Perú (Gose, 2004) o Bolivia (Harris, 1982). ${ }^{17}$

En muchos casos una de las motivaciones principales para la celebración jubilosa de estos velorios o velatorios (más allá de la alegría porque el inocente angelito será recibido por la Virgen en el cielo), es la creencia en que los difuntos pueden arrastrar consigo a los vivos, especialmente a los familiares, así como la convicción de que la risa, el ruido, el alcohol u otros estupefacientes alejan el mal, la desgracia y la muerte, por cuanto la alegría, en conjunto, es signo de vitalidad. Ahí está un patrón de creencia común a muchos pueblos, que explica que encontremos semejantes comportamientos en América, en Europa y aun en África, como ha observado Jack Goody, cuando narra cómo "los parientes del difunto se ven embromados por los miembros de otro clan, que son los que llamaríamos sus compañeros de chanza" (Goody, 1998: 111).

Subyace en todas estas costumbres el lugar que la risa ha ocupado en los ritos de paso en épocas históricas y culturas diferentes, utilizándola no ya solo como afirmación de la vida (de los que sobreviven al muerto), ni como manifestación de alegría por el paraíso alcanzado por el difunto (explicación teológica que nos daba algún sacerdote en Shaglli, Ecuador), sino sobre todo con la ambivalencia jocoseria con que el ser humano ha vivido los momentos de transitoriedad entre la vida y la muerte, la luz y la oscuridad, el acá y el más allá. Hay que tener en cuenta que el velatorio es un momento liminal —según la terminología propuesta por Van Gennep (1969) —, en el umbral mismo entre los que se quedan y el que se va. Como estado transitorio, posterior a la separación y anterior a la agregación, la liminalidad se caracteriza por el

17 Según los lugares, reciben nombres tan significativos como angelito bailao o muerte alegre (en Colombia), velorio de angelito (Ecuador, Colombia, Venezuela) o fiesta de niño muerto (Puerto Rico). El acuarelista Anton Goering, que exploró los Andes entre 1866 y 1874, tuvo ocasión de asistir a algún velorio de angelito en Venezuela, en el transcurso del cual se bebe, se danza y se improvisan canciones dedicadas al angelito. "Parece ser que en los velorios se cometen muchos abusos. Por lo menos me han contado que el pequeño cadáver es llevado de choza en choza y de esta manera tienen ocasión de celebrar cada noche un holgorio" (Goering, 1962: 76). En Chile, los velorios de angelitos han estado muy divulgados en las zonas rurales, y en algunos era preceptivo bailar y festejar durante una semana, estando censurado el llanto, especialmente de la madre. La Iglesia ha combatido este tipo de religiosidad jocosa, y ha considerado ofensivas al sentimiento cristiano unas fiestas que acababan frecuentemente con borracheras y desórdenes (Salinas, 2005: 287308). 
desanclaje de las normas y las convenciones que rigen durante los estados estructurales (separación y agregación), de ahí que encontremos frecuentemente comportamientos turbulentos, incluso degradantes con el que está en tránsito. Por eso los antropólogos hemos observado en muchas culturas cómo el propio difunto es objeto de burlas en forma de duelos de canciones satíricas, como las que observó Evans-Pritchard entre los azande (1978: 108-109).

También la Natividad, el solsticio de invierno, el fin de año, son momentos liminales, en que se transita de un período marcado por la oscuridad, las tinieblas, la muerte a un nuevo período de esplendor, y también ahí hace aparición la risa religiosa. La venida de Cristo inaugura el tiempo de luz, esperanza y redención y acaba con el reino de la muerte, el pecado y el diablo; el solsticio de invierno marca el triunfo del sol y pone fin a la progresiva mengua de los días (con el predominio de la oscuridad); el año nuevo, en fin, permite al hombre renovar su esperanza y dejar atrás, con el año viejo, lo caduco. Es el de los velatorios solo un ejemplo donde se verifica, al igual que hemos comprobado en las fiestas del ciclo navideño, la común vivencia y representación de unas situaciones vitales que han afectado de manera parecida a distintos pueblos $y$ que han merecido dramatizaciones rituales igualmente semejantes. Vista así, la risa natal, las fiestas de locos y en general la comicidad navideña son tan paganas como cristianas, tan profanas como sagradas, y han coexistido mensajes de laicos y clérigos denostándolas, pero también justificándolas. Focalizar sobre su naturaleza sagrada o profana es más bien una cuestión de perspectiva, que de interpretaciones excluyentes. Históricamente, tanto los teólogos como los estudiosos han hecho hincapié en la faceta profana de estas fiestas, razón por la que se las ha llamado carnavalescas. Pero así como no existe Carnaval sin su Cuaresma, es imposible comprender estas prácticas lúdico-festivas sin tomar en consideración también su lado religioso, que aparece en las voces de aquellos que, dentro de la Iglesia, hicieron suyo -modificándolo e insertándolo dentro de una particular teología - todo un vasto mundo de comicidad, que naturalmente tenía sus paralelismos con lo que hacían miembros no clericales de la sociedad.

Los antropólogos hemos observado en culturas alejadas entre sí la extendida concepción según la cual la risa es la máxima manifestación de la vida, idea que no sido ajena a cierta teología. "Ha nacido nuestra sonrisa, ha nacido nuestro Cristo", cantaba Antonio de Padua. En el reino de los muertos, explica Propp (1983) analizando antiguos mitos europeos, no hay risa. Por ello el nacimiento de Cristo y su resurrección (cuando vuelve a la vida), son los momentos claves en que teológicamente tiene sentido la risa vitalista. La antropóloga y teóloga María Caterina Jacobelli (1991: 77-81) trae a colación diversos 
testimonios, desde Aristóteles a exóticos rituales como el de los Jakuti, un pueblo del Asia septentrional, que tienen en común la concepción de la risa no solamente como respuesta al nacimiento, sino como acto que intrínsecamente es necesario para suscitar la vida del neonato o, incluso, para provocar la preñez en las mujeres.

De la misma manera la risa es esencial en los ritos de paso que resaltan la creación o re-creación cíclica, el nacimiento o el re-nacimiento (la resurrección). Como demuestra Van Gennep (1969) y otros que le han seguido — Victor Turner, por ejemplo (1988)—, ciertos ritos de paso son representados, especialmente en su momento liminal, con comportamientos que escenifican turbulencia, confusión, que dramatizan así la ruptura con lo viejo y el nacimiento de lo nuevo, recalcando con ambigüedad la muerte y la vida simultáneamente. Así es lógico que aparezcan en fechas liminales fiestas que ensalzan el desorden simbólico y que permiten cierta violencia y desenfreno, limitados ritualmente. Es el fruto simbólico del "antagonismo biocosmológico" (Del Campo y Corpas 2005: 349-350) que experimentan las culturas basadas en dos principios cosmogónicos opuestos (el bien y el mal, verano e invierno, día y noche, fecundidad y esterilidad, vida y muerte). De ahí que, como lúcidamente ha interpretado Bajtin (1995), el pueblo se sirviera de lo grotesco y muy especialmente de sus formas más degradantes y esperpénticas para significar la muerte simbólica de lo viejo y el comienzo, una vez arrastradas por el suelo todas las convenciones, de una nueva época de tranquilidad y sosiego.

La Iglesia conjugó muchas veces esta simbología liminal para describir el milagro del nacimiento de Cristo. La célebre biografía de santos escrita en 1264, conocida como La Leyenda Dorada, se hace eco de las palabras de San Bernardo: "En la única persona de Cristo coexisten lo eterno, lo antiguo y lo nuevo; lo eterno, o sea, la divinidad; lo antiguo, es decir, el cuerpo, que procede de Adán; lo nuevo: el alma, creada en el momento en que fue concebido" (Vorágine, 2004, I: 54). Jacobo de la Vorágine popularizó también la idea, expuesta por San Bernardo, de que en el nacimiento de Cristo "se reunieron realmente Dios y el hombre, la maternidad y la virginidad, la fe y el espíritu humano" (ibídem 54). De entre estos tres milagros, el primero es el más maravilloso, pues "supone la unión de Dios y del barro, de la majestad y de la debilidad, de la máxima sublimidad y de la máxima vileza, puesto que nada hay más alto que Dios y nada más bajo que el fango" (ibídem 54). El misterio del nacimiento viene a entroncarse con otro misterio aún más antiguo, el del eterno ciclo de nacimiento, muerte y resurrección, el misterio de la creación, del nacimiento de un período nuevo y la muerte del viejo, el misterio del nacimiento de la luz en la noche más larga del año. De ahí que la paradoja cristológica de un Dios hecho hombre, de un niño recién nacido que ya guarda en su seno el destino de su propia 
muerte, de un rey de reyes pasando frío en un pesebre, enlazara a la perfección con las paradojas temposensitivas campesinas. Los villancicos se hacen eco de ello. Pensemos en los de Lope de Vega, quien utiliza a menudo estribillos populares, como el que comienza "Norabuena vengáis al mundo", y pinta la escena del nacimiento con el regocijo propio del que experimenta la llegada del Redentor para espantar las penas: "Que os den parabienes, / y que os hagan fiestas" (Montero, 1960: 59). Es una alegría paradójica, como lo es el propio nacimiento divino: "Lloráis entre las pajas, / del frío que tenéis" (ibídem 56), y paralelamente el propio Niño, en medio de tinieblas invernales, "se ríe en medio del llanto" (ibídem 61). Este es el mensaje cristiano de la Navidad, liminalidad hecha poesía: "Dormid entre las pajas, / que aunque frías las veis, / hoy son flores y rosas, / mañana serán hiel" (ibídem 56). El nacimiento de Cristo es nuestra salvación, y su propia condena. Estas mismas pajas que "tan blandas hoy se ven, / serán mañana espinas / en corona cruel" (ibídem 56). Es el eterno ciclo de nacimiento, muerte y renacimiento, el ciclo bipolar de verano e invierno, luz y oscuridad, risa y llanto, vida y muerte, el que se pone en acción ritual, mitológica y poéticamente.

Así, no es casualidad que determinados comportamientos cómicofestivos aparezcan en las dos pascuas principales: la de Navidad y la de Resurrección. Sabido es que pascua proviene del latín y este de una variante hebrea de pésaj, con el significado de 'paso', 'tránsito'. Para deslindar las dos pascuas principales el pueblo llamó a la segunda pascua florida o pascua de flores, "porque empieza por entonces la primavera", dice el Diccionario de Autoridades de 1737, y al ciclo navideño pascua de Navidad o pascuas en plural. Si en una irrumpe la estación de las flores y la esperanza, la otra celebra el nacimiento del niño sol en la noche más larga del año, y con ello el triunfo del bien sobre el mal. "Lo que hay de notable en el Nacimiento del Salvador, es, que de la obscuridad de su cuna salen el esplendor, y el poder", escribe un teólogo a finales del XVIII (Montargón, 1796, VIII: 102). El misterio del ciclo vital de luz y oscuridad es el mismo que representa el misterio de la Natividad. Tanto la Pascua de Navidad como la Pascua florida -en mucho mayor medida que la tercera de las Pascuas, la de Pentecostésson los momentos de mayor alegría cristiana. Estar como una Pascua es, para el Diccionario de Autoridades, "phrase que vale estar alegre y regocijado [...] porque el tiempo de Pascua es de regocijo y contento" (Autoridades, 1990, III: 190). Una y otra han aglutinado en toda Europa durante siglos diversas manifestaciones de alegría festiva, entre las que no han faltado prácticas clericales que concretaban dicho regocijo en comportamientos burlescos, no demasiado diferentes de los que divertían al pueblo, aunque conservaran un sentido teológico. Maria Caterina Jacobelli (1991), que ha rastreado las muestras del risus paschalis (risa pascual) especialmente en el siglo XVI, lo considera el 
"fundamento teológico del placer sexual", subtítulo de su libro. Si ciertas celebraciones navideñas desataban el escándalo periódicamente, no menos controvertidas eran las desconcertantes costumbres burlescas con que algunos predicadores aliñaban la misa de Pascua de Resurrección, en la que se permitía que el sacerdote incitara a la risa a sus feligreses mediante palabras lascivas, chascarrillos, gestos irreverentes, remedos de animales, obscenidades como imitar masturbarse como un histrión (sicut histrio) o presentar a los feligreses "cosas que los cónyuges suelen ocultar en su dormitorio y que conviene hacer sin testigos" (Jacobelli, 1991: 20). Pese a la oposición de una parte de la Iglesia, ciertos teólogos y predicadores como Wolfgang Capito (1478-1541), de la catedral de Basilea, consideraba lícito y deseable que el predicador hiciera lo posible para que los creyentes acogieran a Cristo resucitado con una alegría desbordada y chabacana (laetitia scurrili excipere) (Jacobelli, 1991: 20-21). Esta hilaridad habría de vincularse pues al caos liminal, previo a todo comienzo o renovación ritual, pero simultáneamente al valor que diferentes religiones han dado al sexo y la risa como fundamentales signos del eterno y universal mito del nacimiento y resurrección.

Risus natalis y risus paschalis constituían ingredientes esenciales de la particular laetitia que había de acompañar las dos Pascuas principales. Por eso no extraña que en la denuncia ante la Inquisición que un religioso antepusiera en 1663 contra las monjas de la Capilla del Convento Real de las Descalzas, este declarara que las monjas se dedicaban a cantar villancicos indecorosos y cometieran otras indecencias especialmente en Sábado Santo y la noche de Navidad, es decir, en los momentos liminales cuando el cristiano $-y$ muy especialmente los miembros más comprometidos con la acción religiosa- debían no solo celebrar jubilosamente el nacimiento o renacimiento, sino propiciarlo con una comicidad burlesca que parecía idénea para escenificar la paradójica y contradictoria coexistencia de la luz y la oscuridad, la vida y la muerte, lo humano y lo divino, lo sagrado y lo profano, lo sublime y lo ínfimo. La burla, que implica al mismo tiempo la degradación y la jovialidad, la muerte simbólica de aquello que desata la risa y la exaltación vitalista (en definitiva una renovación, un renacimiento que requiere acabar con lo viejo y podrido) ha sido fiel compañera de esta lógica -en diferentes épocas y culturas- acaso porque la risa que deriva de ella constituye una de las acciones más ambivalentemente simbólicas con la que acompañar el tránsito en los ritos de paso, en donde se pone de manifiesto con especial énfasis la inexorable y paradójica ley pendular de la mudanza y la estabilidad, algo que ha experimentado el hombre en todas las épocas. 


\section{CONCLUSIÓN}

Nuestro estudio concluye reconociendo a la alegría y la risa el lugar sagrado que ha tenido durante gran tiempo en las celebraciones navideñas, así como interpretando histórica, antropológica y teológicamente el carácter ambivalente de la locura festiva, asumida por una parte de la Iglesia (en el sentido cristiano, es decir, como comunidad de fieles) para representar y vivir ritualmente ciertos valores religiosos: humildad, solidaridad con los desprotegidos, alegría pascual, así como una liberación efímera en el marco de la eutrapelia que permite el juego y las inversiones de roles. Mantenemos por lo tanto que si en un principio las prácticas cómico-festivas durante la Navidad pudieron estar en sintonía con los esparcimientos de los pueblos precristianos, especialmente el romano, con los siglos alcanzaron una fundamentación teológica propia, si bien esta no se expresa, salvo excepciones, de manera inequívoca. Por otro lado hemos argumentado que esta turbulencia festiva excede el marco religioso cristiano (y el pagano) y se muestra como un ingrediente básico en la mito-lógica ritual en torno al solsticio de invierno, el año nuevo y el nacimiento de una deidad en el marco del inmortal ciclo de vida, muerte y regeneración.

Solo conociendo las diferentes motivaciones de los que participan hoy en estas fiestas, los nada inequívocos mensajes que con dichas fiestas se expresan, las complejas funciones que articulan estas costumbres, y muy especialmente poniendo énfasis en conocer el papel que juegan los miembros de la clerecía, es posible —creemos- llegar a reconocerlas como parte de una religiosidad cómica -o jocoseria, por utilizar un término del Siglo de Oro- que siempre ha coexistido, no sin conflictos, con otras formas de fe, culto y festividad. Indagar, por ejemplo, la sanción positiva, negativa o ambivalente que merecen estas fiestas a los sacerdotes que, a través de sermones habitualmente, tienen ocasión de realizar una exégesis desde su particular moral, resulta tan esclarecedor como comprobar el papel activo que juegan en ciertos rituales. Así no está desprovisto de significación el hecho de que el párroco que oficia la misa en el día de los Inocentes en Puebla de Don Fadrique (Granada), lo haga en presencia de los cascaborras e inocentes (personajes burlescos que protagonizan dicha fiesta) e incluso permita que aquellos aporreen las paredes del templo con el palo de mismo nombre (cascaborra), mientras el sacerdote viste al Niño Jesús con el mismo colorido traje de estos personajes que siembran el terror ritualmente entre el 25 y el 28 de diciembre. De la misma manera, quien ha estudiado los autos navideños burlescos que bajo el nombre de pastoradas o corderadas aún se representan en algunos pueblos (Díaz y Ponga, 1983), sabe que el párroco del lugar no siempre censura las bufonadas de los que actúan de pastores en estas representaciones a 
medio camino entre el teatro y el ritual, sino que en ocasiones participa activamente con algún papel. $Y$ son innumerables las muestras de dramaturgia burlesca navideña desde el siglo XIX hasta hoy (zarzuelas, comedias, pastoradas, diálogos dramáticos), asociadas o no a rituales y fiestas populares, pero creadas y promovidas en muchos casos por religiosos que no han abandonado el registro cómico del pastor bobo o el tópico del escarnio jocoso del malvado, adaptando el singular prodesse et delectare que ha merecido la Navidad desde antiguo (Del Campo, 2010).

La antropología social ha sido tal vez la disciplina que más ha intentado interpretar el sentido de las fiestas burlescas invernales, aunque no se haya preocupado siempre de vincularlas históricamente al corpus de creencias cristiano. La toma en consideración de este aspecto, y muy especialmente el análisis histórico del sentido que estas fiestas han jugado entre los clérigos, demuestra que la fiesta no fue un simple combate entre Carnal y Cuaresma, y que la risa no fue patrimonio del diablo, el bufón o eso que de manera un tanto simplista se ha venido a llamar cultura popular, un reduccionismo que implica la existencia por oposición de otro cajón de sastre: la cultura eclesiástica. Por el contrario, una parte de la Iglesia comprendió, aceptó, incluso alentó la risa natal, no solo haciendo la vista gorda con desórdenes festivos tomados por paganos y profanos, sino asignándole hondos y diversos sentidos religiosos.

Quizá sea también esto -y no solo el arraigo de costumbres precristianas entre los pagani y su imposible erradicación- lo que explique la pervivencia de la burla entre laicos y clérigos en la celebración de la Navidad.

BIBILIOGRAFÍA

Amades, J. 1950. Costumari Català. El curs de l'any. Vol. I. Barcelona: Salvat Editores. Provincial.

Amezcua, M. 1997. Crónicas de cordel. Jaén: Diputación

Arce de Otálora, J. 1995. Los coloquios de Palatino y Pinciano. Edición de José Luis Ocasar Ariza. 2 vols. Madrid: Fundación José Antonio de Castro, Turner. 
Arlt, W. 1970. Ein Festoffizium des Mittelalters aus Beauvais in seiner liturgischen und musikalischen Bedeutung. 2 vols. Colonia: Arno Volk Verlag.

Autoridades, Diccionario de. 1990. Real Academia Española. 3 vols. Madrid: Gredos.

Bajtin, M. 1987. La cultura popular en la Edad Media y en el Renacimiento. El contexto de François Rabelais. Madrid: Alianza Editorial. de Navarra.

Baleztna, J. 1979. El rey de la Faba. Pamplona: Diputación Foral

Bayless, M. 1996. Parody in the Middle Ages: the Latin tradition. Michigan: The University of Michigan Press.

Braga M. de. 1981. Sermón contra las supersticiones rurales. Texto revisado y traducción de Rosario Jove Clols. Barcelona: Ediciones El Albir.

Bravo-Villasante, C. (ed.). 1978. Villancicos del siglo XVII y XVIII. Madrid: Editorial Magisterio Español.

Burucúa, J. E. 2001. Corderos y elefantes. La sacralidad y la risa en la modernidad clásica. Siglos XV a XVII. Madrid y Buenos Aires: Miño y Dávila, Universidad de Buenos Aires.

Caro Baroja, J. 1965. El Carnaval. Análisis histórico-cultural. Madrid: Taurus.

Caro Baroja, J. 1979. Ensayos sobre la cultura popular española. Madrid: Editorial Dosbe.

Caro Baroja, J. 1985. Las formas elementales de la vida religiosa (siglos XVI y XVII). Madrid: Sarpe. Calpe.

Caro, R. 1978. Días geniales o lúdricos. 2 vols. Madrid: Espasa-

Casas de las, fray B. 1909. Historiadores de Indias. I. Madrid: NBAE, XIII.

Castro, E. 1996. Introducción al teatro latino medieval. Textos y públicos. Santiago de Compostela: Universidad de Santiago de Compostela. 
Ciudad, R. 1987. "El baile de las ánimas de Almedina (Ciudad Real)" en Actas de las III Jornadas de Etnología de Castilla La Mancha: 293-298. Toledo: JCMM.

Covarrubias de Orozco, S. 1995. Tesoro de la Lengua Castellana o Española. Edición de Felipe C.R. Maldonado, revisada por Manuel Camarero. Madrid: Editorial Castalia.

Del Campo Tejedor, A.; Corpas García, A. 2005. El mayo festero. Ritual y Religión en el triunfo de la primavera. Sevilla: Fundación José Manuel Lara, Editorial Planeta.

Del Campo Tejedor, A. 2006. "Mal tiempo, tiempo maligno, tiempo de subversión ritual. La temposensitividad agrofestiva invernal". Revista de Dialectología y Tradiciones Populares 61/1: 103-138.

Del Campo Tejedor, A. 2008. "Hacer el loco. Muerte, miedo y subversión en torno a la Navidad" en VI Jornadas de Protección del Patrimonio Histórico de Écija: 103-143. Écija.

Del Campo Tejedor, A. 2009. "Diversiones clericales burlescas en los siglos XIII al XVI: las misas nuevas". La Corónica, A Journal of Medieval Hispanic Languages, Literatures and Cultures 38. I: 55-95.

Del Campo Tejedor, A. 2010. "El teatro religioso navideño de la Restauración. Continuismo y adaptación de una tradición didácticoburlesca". Bulletin Hispanique 112, 2: 671-716.

Del Campo Tejedor, A. 2012. Tratado del burro y otras bestias. Una historia del simbolismo animal en Occidente. Sevilla: Aconcagua.

Díaz, J.; Alonso Ponga, J.L. 1983. Autos de Navidad en León y Castilla. León: Santiago García editor.

Erasmo de Rotterdam, D. 2002. Elogio de la locura o Encomio de la Estulticia. Introducción de José Antonio Marina, edición y traducción de Pedro Voltes. Madrid: Espasa-Calpe.

Evans-Pritchard, E. 1978. La relación hombre-mujer entre los azande. Barcelona: Editorial Crítica.

Fradejas, J. 1996. "Fray Hernando de Talavera y el teatro: `el obispillo'". Epos, Revista de Filología 12: 457-472. 
Frankfort, H.; Frankfort, H. Mrs.; Wilson, J.A.; Jacobsen, T. 1951. Before Philosophy. A Study of the primitive myths, beliefs, and speculations of Egypt and Mesopotamia, out of which grew the religions and philosophies of the later world. Harmondsworth: Penguin.

Friedberg, A. 1878-1881. Corpus Iuris Canonici. Ediptio lipsienis secunda. Pars Prior, Decretum Magistri Gratiani, Pars Secunda, Decretalium Collectionum: Lipsiae.

Gaignebet, C. 1984. El Carnaval. Ensayos de mitología popular. Barcelona: Editorial Alta Fulla. BAC.

García y García, A. 1990. Synodicon Hispanum. Vol. V. Madrid: BAC.

García y García, A. 1993. Synodicon Hispanum. Vol. VI. Madrid:

García y García, A. 2007. Synodicon Hispanum. Vol. VIII. Madrid: BAC.

García Mercadal, J. 1999. Viajes de Extranjeros por España y Portugal, desde los tiempos más remotos hasta comienzos del siglo XX. Salamanca: Junta de Castilla y León, Consejería de Educación y Cultura.

Giordano, O. 1995. Religiosidad popular en la Alta Edad Media. Madrid: Gredos.

Goering, A. 1962. Venezuela, el más bello país tropical. Mérida: Universidad de Los Antes.

Goody, J. 1998. El hombre, la escritura y la muerte. Conversación con Pierre-Emmanuel Dauzat. Barcelona: Península.

Gose, P. 2004. Aguas mortíferas y cerros hambrientos. Ritos agrarios y formación de clases en un pueblo andino. Quito-Ecuador: Abya-Yala.

Granada de, fray Luis. 1999. Obras completas. Vol. 24. Sermones de tiempo l/1. Transcripción y traducción de Ricardo Alarcón Buendía, edición y notas de Álvaro Huerga. Madrid: Fundación Universitaria Española, Dominicos de Andalucía.

Granada de, fray Luis. 2004. Obras completas. Vol. 41. Sermones de santos 1/3. Traducción de Donato González-Reviriego, edición y notas 
de Álvaro Huerga, Madrid: Fundación Universitaria Española, Dominicos de Andalucía.

Harris, O. 1982. "The dead and the devils among the Bolivian Laymi" en M. Bloch y J. Parry (comps.), Death and the regeneration of life: 45-73. Cambridge: Cambridge University Press. Península.

Heers, J. 1988. Carnavales y fiestas de locos. Barcelona:

Jacobelli, M.C. 1991. Risus Paschalis. El fundamento teológico del placer sexual. Barcelona: Planeta.

Jean-Paul (Richter, J.P.). 1836. Pensées de Jean Paul, extraites de tous ses ouvrages; traduites de l'allemand par M. le M. de la Grange. París-Estrasburgo.

Le Goff, J. 2006. I riti, il tempo, il riso, cinque saggi di storia medievale. Bari: Editori Laterza.

Le Roy Ladurie, E. 1980. Carnival. A People's Uprising at Romans 1579-1580. Londres: Scholar Press.

Lévi-Strauss, C. 2000. Antropología estructural. Barcelona: Paidós.

Limón, A. 1981. Costumbres populares andaluzas de nacimiento, matrimonio y muerte. Sevilla: Diputación de Sevilla.

López Alonso, C. 1988. Locura y Sociedad en Sevilla: historia del Hospital de los Inocentes (1436 ?-1840). Sevilla: Diputación de Sevilla.

López de Ayala y Álvarez de Toledo, J. 1901. "Sobre una curiosa práctica en la Catedral de Toledo. El Obispillo de San Nicolás", en Toledo en el siglo XVI después del vencimiento de las comunidades. Madrid.

Massip, F. 1992. El teatro medieval. Voz de la divinidad, cuerpo de histrión. Barcelona: Montesinos editor.

Milá y Fontanals, M. 1895. Obras Completas. Vol. VI. Opúsculos Literarios. Barcelona: Librería de Álvaro Verdaguer.

Minois, G. 2005. Historia de los infiernos. Barcelona: Paidós.

Montargón, J. fr. 1785. Diccionario apostolico. Madrid: Imprenta de Don Benito Cano. 
Montero, L. 1960. Poesía religiosa española (Antología). Zaragoza: Editorial Ebro.

Owst, G. R. 1966. Literature and pulpit in Medieval England. Oxford: Basil Blackwell.

Paz y Melia, A. 1964. Sales españolas o Agudezas del ingenio nacional. Madrid: BAE, Atlas.

Plandolit, L. J. 1963. El Apóstol de América San Francisco Solano. Madrid: Editorial Cisneros.

Prévot, B. 2004. "Festum baculi: fête du bâton ou fête des fous à Châlons, au Moyen Age", en Mougin, S., Grossel, M.-G. (eds.), Poésie et Rhétorique du non-sens: littérature médiévale, littérature oral. Reims: Presses universitaires de Reims.

Propp, V. 1983. Edipo a la luz del Folklore y otros ensayos de etnografía. Barcelona: Bruguera.

Salinas, M. 2005. Canto a lo divino y religión popular en Chile hacia 1900. Santiago de Chile: LOM Ediciones.

Satrústegui, J. Mª. 1988. Solsticio de invierno. Iruñea, Estella: Gráf. Lizarra.

Strecker, K. 1964. Monumenta Germaniae historica: poetae latini aevi carolini. Vol. IV-2. Berlín: Weidmann.

Turner, V. 1988. El proceso ritual. Estructura y antiestructura. Madrid: Taurus.

Van Gennep, A. 1969. Les rites de passage. París: Mouton.

Villalón, C. de. 1982. El Crotalón. Edición de Asunción Rallo. Madrid: Cátedra. Forma.

Vorágine S. de la. 2004. La leyenda dorada. 2 vols. Madrid: Alianza

Vyncke, F. 1992. "La religión de los eslavos" en Puech, H.-C., Historia de las Religiones. Vol. 3. Las religiones antiguas. Madrid: Siglo Veintiuno. 